In cooperation with the San Antonio Water System

\title{
Simulation of Streamflow and Estimation of Recharge to the Edwards Aquifer in the Hondo Creek, Verde Creek, and San Geronimo Creek Watersheds, South-Central Texas, 1951-2003
}

Scientific Investigations Report 2005-5252 
Blank Page 


\section{Simulation of Streamflow and Estimation of Recharge to the Edwards Aquifer in the Hondo Creek, Verde Creek, and San Geronimo Creek Watersheds, South-Central Texas, 1951-2003}

By Darwin J. Ockerman

In cooperation with the San Antonio Water System

Scientific Investigations Report 2005-5252 


\section{U.S. Department of the Interior Gale A. Norton, Secretary}

\section{U.S. Geological Survey \\ P. Patrick Leahy, Acting Director}

\section{U.S. Geological Survey, Reston, Virginia: 2005}

For sale by U.S. Geological Survey, Information Services

Box 25286, Denver Federal Center

Denver, CO 80225

For more information about the USGS and its products:

Telephone: 1-888-ASK-USGS

World Wide Web: http://www.usgs.gov/

Any use of trade, product, or firm names in this publication is for descriptive purposes only and does not imply endorsement by the U.S. Government.

Although this report is in the public domain, permission must be secured from the individual copyright owners to reproduce any copyrighted materials contained within this report.

Suggested citation:

Ockerman, D.J., 2005, Simulation of streamflow and estimation of recharge to the Edwards aquifer in the Hondo Creek, Verde Creek, and San Geronimo Creek watersheds, south-central Texas, 1951-2003: U.S. Geological Survey Scientific Investigations Report 2005-5252, 37 p. 


\section{Contents}

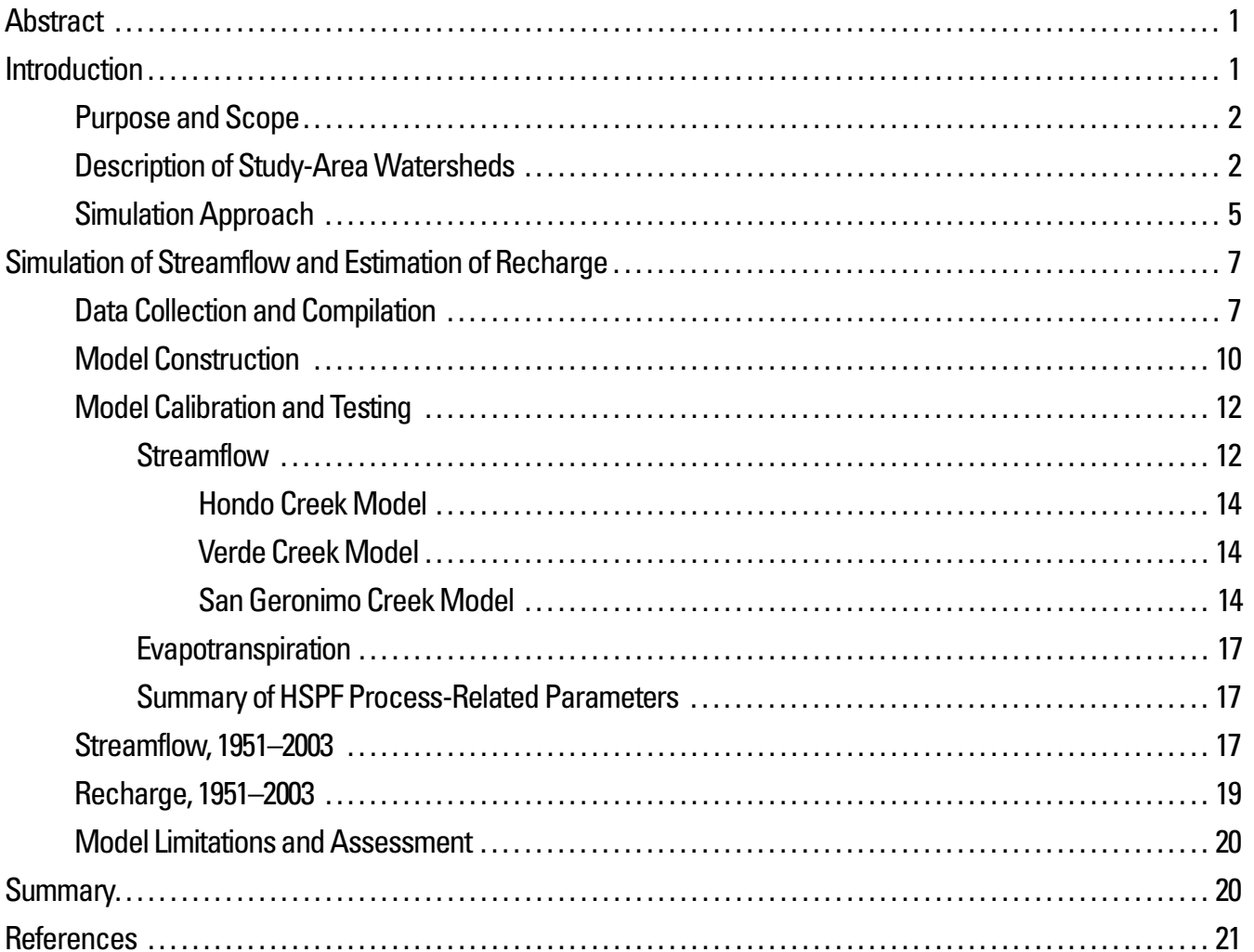

\section{Figures}

1-2. Maps showing:

1. Location of Hondo Creek, Verde Creek, and San Geronimo Creek watersheds,

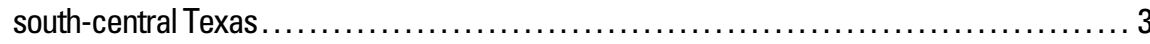

2. Land cover in Hondo Creek, Verde Creek, and San Geronimo Creek watersheds, south-central Texas, early to mid-1990s

3. Diagram showing Hydrological Simulation Program—FORTRAN (HSPF) flowchart for

(a) impervious and (b) pervious land segments

4-6. Maps showing:

4. Location of data-collection sites used for Hydrological Simulation Program-

FORTRAN (HSPF) model calibration, testing, and simulations, Hondo Creek, Verde

Creek, and San Geronimo Creek watersheds, south-central Texas ................... 8

5. Subwatersheds in Hondo Creek, Verde Creek, and San Geronimo Creek watersheds, south-central Texas, for Hydrological Simulation Program—FORTRAN (HSPF) model development.

6. Primary rain gages and associated rainfall areas for Hydrological Simulation

Program—FORTRAN (HSPF) model calibration, testing, and simulations, Hondo

Creek, Verde Creek, and San Geronimo Creek watersheds, south-central Texas 
7-9. Graphs showing:

7. Measured and simulated daily mean streamflow at U.S. Geological Survey streamflow-gaging station 08200000 Hondo Creek near Tarpley, Texas, 1992-2003 ........ 15

8. Measured and simulated daily mean streamflow at U.S. Geological Survey streamflow-gaging station 08200700 Hondo Creek at King Waterhole near Hondo,

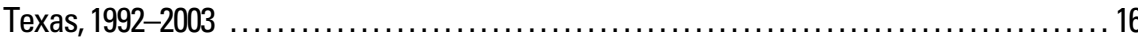

9. Measured and simulated daily mean streamflow at U.S. Geological Survey streamflow-gaging station 08180590 San Geronimo Creek Reservoir inflow near Rio Medina, Texas, 1992-93. 18

\section{Tables}

1. Process-related model parameters for the Hydrological Simulation Program—FORTRAN . . . . . 7

2. Basin-related model parameters for the Hydrological Simulation Program—FORTRAN .......... 7

3. Data-collection stations used for Hydrological Simulation Program —FORTRAN model input, calibration, and simulations for Hondo Creek, Verde Creek, and San Geronimo Creek watersheds, south-central Texas

4. Sources of rainfall data used to provide missing record and time-step disaggregation for primary rainfall time series used in the Hydrologic Simulation Program—FORTRAN (HSPF) model, Hondo Creek, Verde Creek, and San Geronimo Creek watersheds, south-central

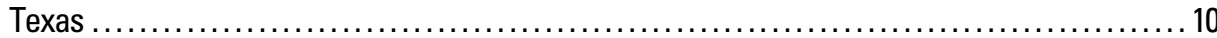

5. Subwatershed drainage areas, Hondo Creek, Verde Creek, and San Geronimo Creek watersheds, south-central Texas

6. Streamflow calibration and testing results, Hydrological Simulation Program—FORTRAN model, Hondo Creek watershed, south-central Texas, 1992-2003

7. Streamflow testing and recalibration results, Hydrological Simulation Program—FORTRAN model, San Geronimo Creek watershed, south-central Texas, 1992-93

8. Rainfall and simulated evapotranspiration, Hydrological Simulation Program—FORTRAN model, Hondo Creek watershed, south-central Texas, 1992-2003.

9. Process-related annual parameters for pervious and impervious land segments, Hydrological Simulation Program—FORTRAN models, Hondo Creek and Verde Creek watersheds, south-central Texas

10. Process-related annual parameters for pervious and impervious land segments, Hydrological Simulation Program — FORTRAN model, San Geronimo Creek watershed, south-central Texas.

11. Monthly values of lower-zone evapotranspiration (ZZETP) parameter, Hydrological Simulation Program—FORTRAN models, Hondo Creek, Verde Creek, and San Geronimo Creek watersheds, south-central Texas

12. Simulated average annual streamflow volumes for Hondo Creek, Verde Creek, and San Geronimo Creek watersheds, south-central Texas, 1951-2003 35

13. Estimated annual rainfall and Edwards aquifer recharge, Hondo Creek, Verde Creek, and San Geronimo Creek watersheds, south-central Texas, 1951-2003 36

14. Comparison of Edwards aquifer recharge estimates from Hydrological Simulation Program — FORTRAN (HSPF) with historical (Puente method) U.S. Geological Survey recharge estimates for Hondo Creek and Verde Creek watersheds, south-central Texas, 1992-2003 


\title{
Simulation of Streamflow and Estimation of Recharge to the Edwards Aquifer in the Hondo Creek, Verde Creek, and San Geronimo Creek Watersheds, South-Central Texas, 1951-2003
}

\author{
By Darwin J. Ockerman
}

\section{Abstract}

The U.S. Geological Survey, in cooperation with the San Antonio Water System, constructed three watershed models using the Hydrological Simulation Program-FORTRAN (HSPF) to simulate streamflow and estimate recharge to the Edwards aquifer in the Hondo Creek, Verde Creek, and San Geronimo Creek watersheds in south-central Texas. The three models were calibrated and tested with available data collected during 1992-2003. Simulations of streamflow and recharge were done for 1951-2003. The approach to construct the models was to first calibrate the Hondo Creek model (with an hourly time step) using 1992-99 data and test the model using 2000-2003 data. The Hondo Creek model parameters then were applied to the Verde Creek and San Geronimo Creek watersheds to construct the Verde Creek and San Geronimo Creek models. The simulated streamflows for Hondo Creek are considered acceptable. Annual, monthly, and daily simulated streamflows adequately match measured values, but simulated hourly streamflows do not. The accuracy of streamflow simulations for Verde Creek is uncertain. For San Geronimo Creek, the match of measured and simulated annual and monthly streamflows is acceptable (or nearly so); but for daily and hourly streamflows, the calibration is relatively poor. Simulated average annual total streamflow for 1951-2003 to Hondo Creek, Verde Creek, and San Geronimo Creek is 45,400; 32,400; and 11,100 acre-feet, respectively. Simulated average annual streamflow at the respective watershed outlets is 13,000; 16,200; and 6,920 acre-feet. The difference between total streamflow and streamflow at the watershed outlet is streamflow lost to channel infiltration. Estimated average annual Edwards aquifer recharge for Hondo Creek, Verde Creek, and San Geronimo Creek watersheds for 1951-2003 is 37,900 acre- feet (5.04 inches), 26,000 acre-feet (3.36 inches), and 5,940 acre-feet (1.97 inches), respectively. Most of the recharge (about 77 percent for the three watersheds together) occurs as streamflow channel infiltration. Diffuse recharge (direct infiltration of rainfall to the aquifer) accounts for the remaining 23 percent of recharge. For the Hondo Creek watershed, the HSPF recharge estimates for 1992-2003 averaged about 22 percent less than those estimated by the Puente method, a method the U.S. Geological Survey has used to compute annual recharge to the Edwards aquifer since 1978. HSPF recharge estimates for the Verde Creek watershed average about 40 percent less than those estimated by the Puente method.

\section{Introduction}

The Edwards aquifer is one of the most productive aquifers in the United States and is the major source of public water supply for San Antonio and numerous smaller municipalities in south-central Texas. In addition, the Edwards aquifer supplies large quantities of water for agriculture, industry, military installations, and recreational activities. The aquifer also is a source of water to major springs in the region. These springs provide habitat for several threatened and endangered species and supply water to downstream users.

Parts of each of the study-area watersheds are within the recharge zone of the Edwards aquifer. Recharge to the Edwards aquifer is an important issue for water-resource managers in the San Antonio area. As part of a continuing program in cooperation with the Edwards Aquifer Authority (EAA), the U.S. Geological Survey (USGS) computes annual estimates of Edwards aquifer recharge. These estimates are based on a method for computing recharge developed by Puente (1978) using data 


\section{Simulation of Streamflow and Estimation of Recharge to the Edwards Aquifer, South-Central Texas, 1951-2003}

collected from a network of USGS streamflow-gaging stations and a network of rain gages, some operated by the National Weather Service (NWS) and some by the EAA. The USGS has compiled annual estimates of Edwards aquifer recharge from 1934 to present (2004).

The method to estimate Edwards aquifer recharge (hereinafter referred to as the Puente method) uses monthly time periods. A watershed model, which uses smaller time steps (hourly) that more realistically simulate the relatively rapid rainfallrunoff-recharge processes in the study-area watersheds, might provide a more accurate estimation of aquifer recharge for these watersheds. Also, a calibrated watershed model enables predictive scenarios to estimate changes in recharge resulting from land-use changes including implementation of bestmanagement practices (BMPs). Removal of juniper (Juniperus ashei) trees (Owens and others, 2001), construction of floodcontrol or recharge-enhancement structures (HDR Engineering, 1998), and rainfall enhancement (Edwards Aquifer Authority, 2004) are examples of BMPs that have been proposed or implemented in the three or similar watersheds in the region.

To address the need for accurate recharge estimates for the Edwards aquifer, the USGS, in cooperation with the San Antonio Water System conducted a study to apply a watershed model to simulate streamflow and recharge to the Edwards aquifer in the Hondo Creek, Verde Creek, and San Geronimo Creek watersheds in south-central Texas (fig. 1).

\section{Purpose and Scope}

The purpose of this report is to document application of the Hydrological Simulation Program-FORTRAN (HSPF) watershed model (Bicknell and others, 2001) to simulate streamflow and estimate recharge to the Edwards aquifer in the Hondo Creek, Verde Creek, and San Geronimo Creek watersheds. Calibration and testing of a model for each watershed are based on data collected during 1992-2003. Model simulations of streamflow and estimates of recharge are provided for 1951-2003. Model estimates of Edwards aquifer recharge also are compared to previous recharge estimates computed by the USGS using the Puente method.

\section{Description of Study-Area Watersheds}

The study-area watersheds are in south-central Texas west of San Antonio, along the southern part of the Edwards Plateau (often referred to as the Texas Hill Country) and near the transition to the Gulf Coastal Plain. The study-area watersheds encompass parts of the Edwards aquifer outcrop, which is essentially coincident with the recharge zone (fig. 1).

Hondo and Verde Creeks are part of the Frio-Nueces River system. Hondo Creek originates in south-central Bandera County and flows southeast for about 65 miles (mi) through Bandera, Medina, and Frio Counties to its confluence with the Frio River about $5 \mathrm{mi}$ northwest of Pearsall. For this study, only the upper part of Hondo Creek, above the confluence with Verde Creek and including 161 square miles $\left(\mathrm{mi}^{2}\right)$ of drainage area, is included in the model simulations. Verde Creek begins in three branches in south-central Bandera County and runs south for about $20 \mathrm{mi}$ to its confluence with Hondo Creek, about 4 mi east of the town of Hondo. The drainage area of the watershed is $219 \mathrm{mi}^{2}$. San Geronimo Creek enters the Medina River, which is part of the San Antonio-Guadalupe River system. San Geronimo Creek, beginning in northwestern Bexar County, runs southwest for about $20 \mathrm{mi}$ through Bexar, Bandera, and Medina Counties to its mouth on the Medina River. The drainage area of the watershed is $68.5 \mathrm{mi}^{2}$.

The study area is described as having a subtropical, subhumid climate, characterized by hot summers and mild, dry winters (Larkin and Bomar, 1983). Heaviest rainfall tends to occur in spring, early summer, and fall, but heavy rainfall can occur throughout the year. Average annual rainfall (1961-90) in the study area is about 30 inches per year (in/yr). The San Antonio average monthly low temperatures range from 37.9 degrees Fahrenheit $\left({ }^{\circ} \mathrm{F}\right)$ in January to $75.0^{\circ} \mathrm{F}$ in July. Average monthly high temperatures range from $60.8^{\circ} \mathrm{F}$ in January to $95.3^{\circ} \mathrm{F}$ in August (Bomar, 1995).

The surface of the area upstream from the Edwards aquifer recharge zone (outcrop), the upper part of each watershed, is composed of Glen Rose Limestone (the uppermost unit of the Trinity aquifer, which is juxtaposed against the northern boundary of the Edwards aquifer). Glen Rose Limestone generally has low permeability compared to rocks of the Edwards Group, which compose almost all of the Edwards aquifer (Clark, 2003). Uneroded remnants of Edwards Group rocks (hilltops) that overlie Glen Rose Limestone in places are moderately permeable but are not connected to the Edwards aquifer. The central part of each watershed is in the Edwards aquifer recharge zone. In the Edwards aquifer recharge zone, outcropping Edwards Group rocks are characterized by high permeability because of faults, sinkholes, and other karst features. Relatively impermeable confining units overlie the Edwards aquifer south of the recharge zone, which is coincident with the lower part of each watershed. Relatively thin alluvial deposits of sand and silt also are at the surface, mainly along stream channels (Small and Clark, 2000).

Streams in the study-area watersheds originate in the topographically rugged Texas Hill Country north of the recharge zone and generally flow south, crossing the recharge zone and continuing onto units that overlie and confine the Edwards aquifer south of the recharge zone. Most, if not all of the streamflow is lost to faults, fractures, caves, and sinkholes as the streams cross the recharge zone. Although major streams on the Glen Rose Limestone outcrop (upstream from the recharge zone) are not classified as perennial, flow is much more frequent than on the Edwards Group outcrop (recharge zone). Hondo Creek at USGS streamflow-gaging station 08200000 Hondo Creek near Tarpley (upstream from the recharge zone) flows more than 90 percent of the time (1952-2004) and in some years is continuous. In contrast, Hondo Creek at USGS streamflow-gaging station 08200700 Hondo Creek at King Waterhole near Hondo 


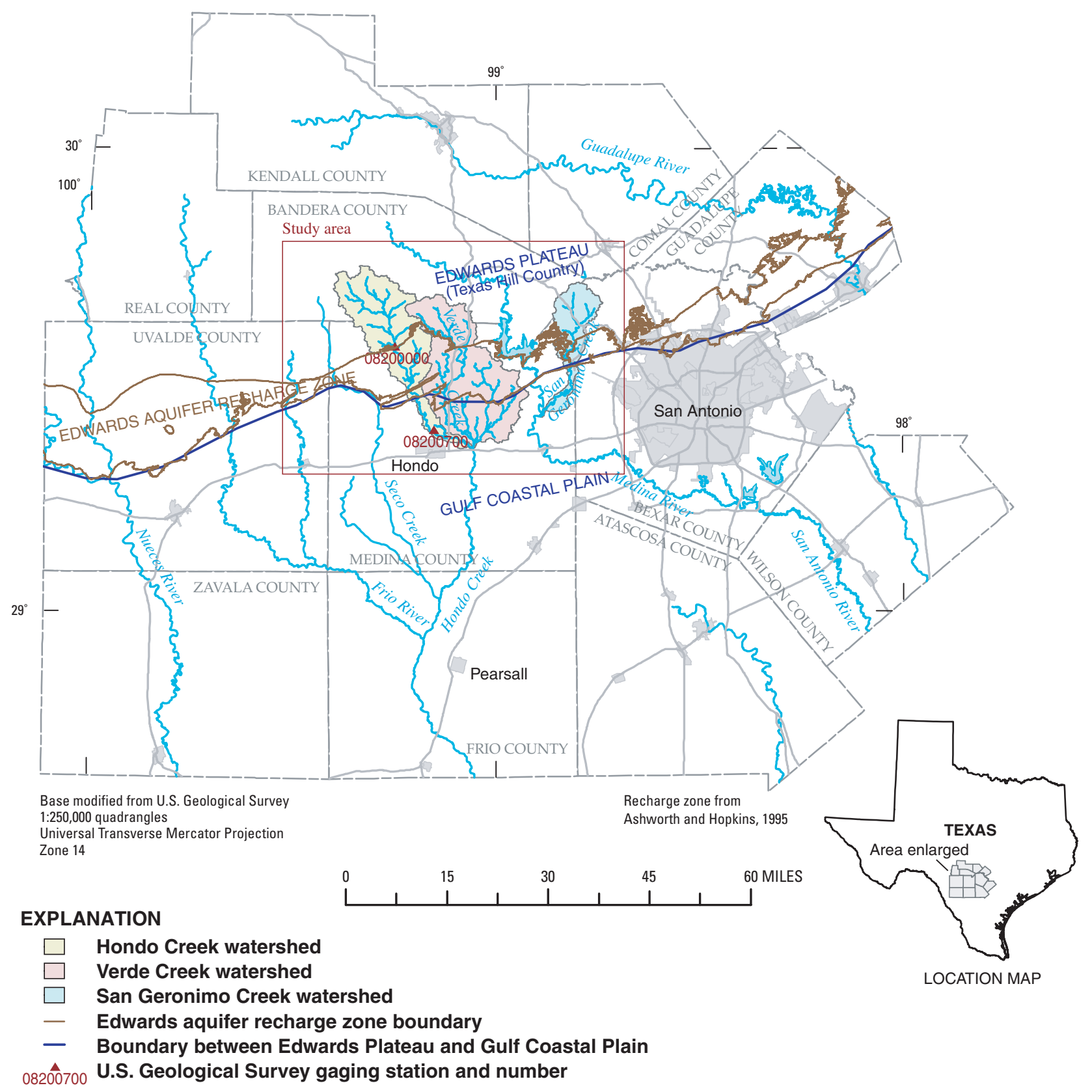

Figure 1. Location of Hondo Creek, Verde Creek, and San Geronimo Creek watersheds, south-central Texas.

(downstream from the recharge zone) flows less than 10 percent of the time (1961-2004) and in some years does not flow (Aragon Long and others, 2005).

Streamflow losses in the Edwards aquifer recharge zone are believed to contribute directly to Edwards aquifer recharge (Puente, 1978; Land and others, 1983). Most recharge to the Edwards aquifer occurs as streamflow losses directly out of channels and other water courses. Infiltration of rainfall, or diffuse recharge, is relatively small compared to recharge occurring through streamflow losses (Maclay, 1995).
Land cover in the study-area watersheds (fig. 2), especially in the upper and middle parts of each watershed, is oak-juniper forest and rangeland (shrubland and grassland). Much of the lower part of each watershed (south of the recharge zone) is pasture and cultivated land. Development in the study-area watersheds is sparse, limited to farms, ranches, and a few small towns.

Land-surface elevation in the study-area watersheds ranges from about 730 to 2,000 feet above sea level. Land slopes generally are steeper in the upper parts of the watershed 


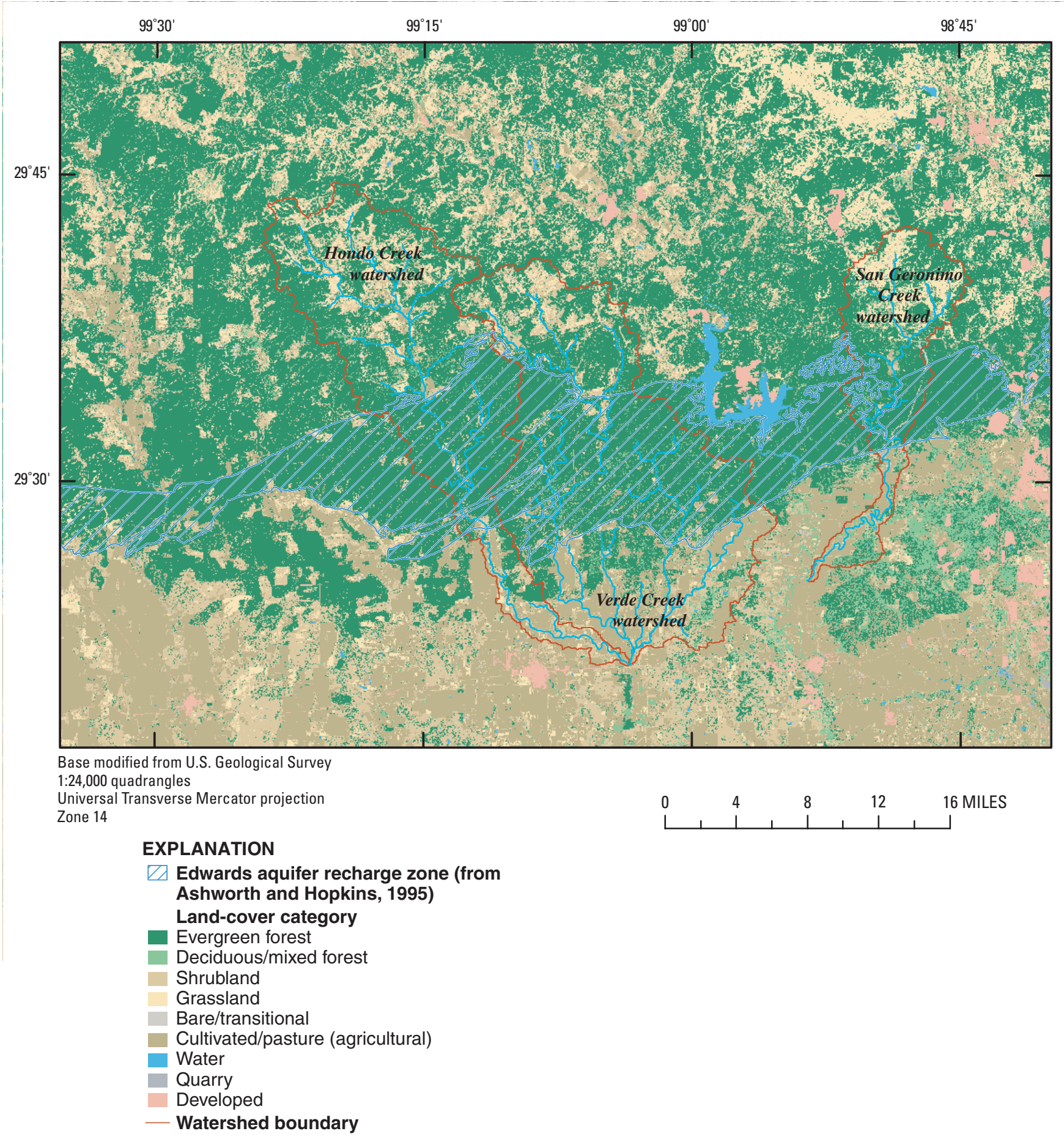

Figure 2. Land cover in Hondo Creek, Verde Creek, and San Geronimo Creek watersheds, south-central Texas, early to mid-1990s (U.S. Geological Survey, 2003).

than in the lower parts. Soils in most of the watersheds, especially upstream from and on the Edwards aquifer recharge zone are thin, rocky, and clayey. In the lower parts of the watersheds, in the transition to Gulf Coastal Plains, the soils are deeper clay and sand loams.
Several small (less than about 1,000 acre-feet [acre-ft]) reservoirs and numerous smaller stock ponds are in the three watersheds. Most of these reservoirs (many constructed in the 1960s and 1970s) are in the upper parts of the watersheds, above the Edwards aquifer recharge zone, and probably have little 
influence on recharge to the Edwards aquifer. However, two structures in the recharge zone in the Verde Creek and San Geronimo Creek watersheds were constructed to enhance recharge to the Edwards aquifer by retaining and allowing for infiltration of streamflow that might otherwise exit the recharge zone (Edwards Aquifer Authority, 2004). The EAA has estimated that these two structures have increased recharge by an average of 1,699 acre-feet per year (acre-ft/yr) since their construction in the late 1970s (Edwards Aquifer Authority, 2004).

Domestic and agricultural water supply in the watersheds is obtained from Edwards aquifer wells in the lower parts and Trinity aquifer wells in the upper parts. No wastewater treatment discharge occurs in the study-area watersheds.

\section{Simulation Approach}

Because numerous watershed characteristics and hydrologic processes affect streamflow and recharge in the study-area watersheds, a comprehensive watershed model was needed to account for the complex interactions between watershed characteristics and hydrologic processes and to simulate streamflow and recharge. Also, a watershed model is necessary to evaluate changes in streamflow and recharge that might occur because of future changes in watershed characteristics (for example, landuse changes and possible implementation of BMPs).

The HSPF model was selected to model the study watersheds because it is one of the most comprehensive watershed models available, can simulate a wide variety of stream and watershed conditions with reasonable accuracy, and enables flexibility in adjusting model inputs to simulate alternative conditions, or scenarios (Donigian and others, 1995). HSPF is a watershed model used to simulate hydrologic processes in complex agricultural, rural, and urban watersheds. HSPF uses such information as the time history of rainfall, temperature, evaporation, and parameters related to land cover, land-use practices, and soil characteristics to simulate the hydrologic processes that occur in a watershed. The result of an HSPF simulation is a time history of the quantity of water transported over the land surface and through the various soil zones down to an aquifer (Donigian and others, 1995).

HSPF is an empirical model; conceptually, the processrelated parameters of the model have physical meaning but are not physically measurable (or are difficult to measure) and must be specified by calibration. The HSPF model is divided into three components to simulate the hydrology of a watershed: pervious areas (segments), impervious areas (segments), and stream (and reservoir) segments. Pervious land conceptually is represented within HSPF by a series of interconnected waterstorage zones: an upper zone, a lower zone, and a ground-water zone. Impervious land is represented by much simpler surface storage, evaporation, and runoff (overland flow) processes. Each user-defined, pervious or impervious land segment represents its own unique hydrologic response on the basis of soil type, land cover, watershed slope, or other important basin char- acteristics. These land segments do not need to be contiguous. Stream or reservoir segments (open or closed channels, or completely mixed lakes) are simulated using hydraulic routing methods (Donigian and others, 1995).

A schematic diagram depicting how HSPF simulates water movement through and across pervious and impervious land to the atmosphere, ground water, or surface runoff is shown in figure 3 . The flow of water between the storage zones, stream, and atmosphere is affected by the process-related parameters listed in table 1.

The process-related model parameters for each land segment are adjusted to calibrate the model. Some processrelated parameters can be adjusted monthly to account for seasonal variations: interception storage capacity (CEPSC), interflow index (INTFW), interflow recession coefficient (IRC), lower-zone evapotranspiration (LZETP), Manning's roughness coefficient (n) for assumed overland flow plane (NSUR), and upper-zone nominal storage (UZSN). For this study, monthly variation was implemented only for the parameter LZETP.

The six basin-related model parameters listed in table 2 define the areal extent of each land segment and other characteristics of each stream or reservoir segment, including length and tables of surface area, volume, and discharge, as a function of depth. Collectively, these parameters represent the physical characteristics of each land or stream segment in a watershed and generally remain unchanged during calibration of the model.

The HSPEXP computerized expert system (Lumb and others, 1994) was used to assist with process-related parameter adjustment for model calibration. The HSPEXP procedures consist of a set of hierarchical rules designed to guide the calibration of the model through a systematic evaluation of the model parameters. Simulation errors are evaluated on the basis of seven criteria: total streamflow volume, lowflow recession, highest 10 percent of daily flow volumes, lowest 50 percent of daily flow volumes, storm volumes, seasonal volumes, and summer storm volumes. Statistics computed by HSPEXP provide the analyst with an evaluation of the agreement between simulated and observed runoff values. Specifically for this study, simulation errors were evaluated by comparing total streamflow volume, 50-percent lowest flows, 10-percent highest flows, and selected storm peaks.

The Hondo Creek watershed includes two long-term gaging stations. Few streamflow data are available from the Verde Creek and San Geronimo Creek watersheds. The approach used in calibrating the study-area watershed models was to first calibrate and test the Hondo Creek model using available data for 1992-2003. Then the resulting calibrated parameters were transferred to the Verde Creek and San Geronimo Creek watersheds to create the Verde and San Geronimo models. The few streamflow data available from the San Geronimo Creek watershed were used for testing transferability of Hondo Creek model parameters to the other two watersheds. 

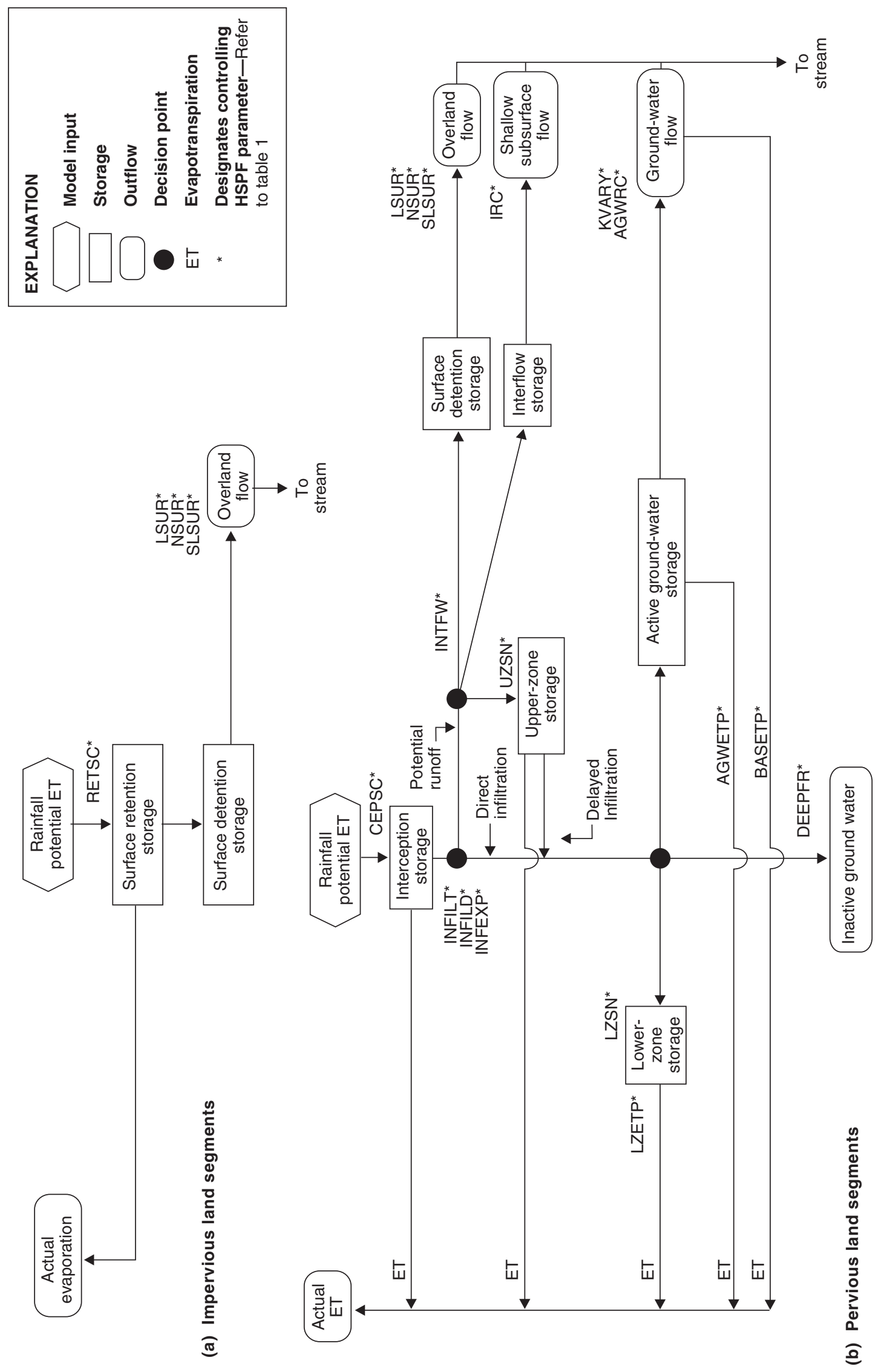

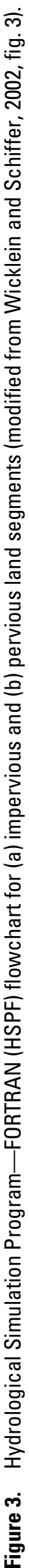


Table 1. Process-related model parameters for the Hydrological Simulation Program—FORTRAN (modified from Wicklein and Schiffer, 2002, table 1).

[PERLND, pervious segment; IMPLND, impervious segment]

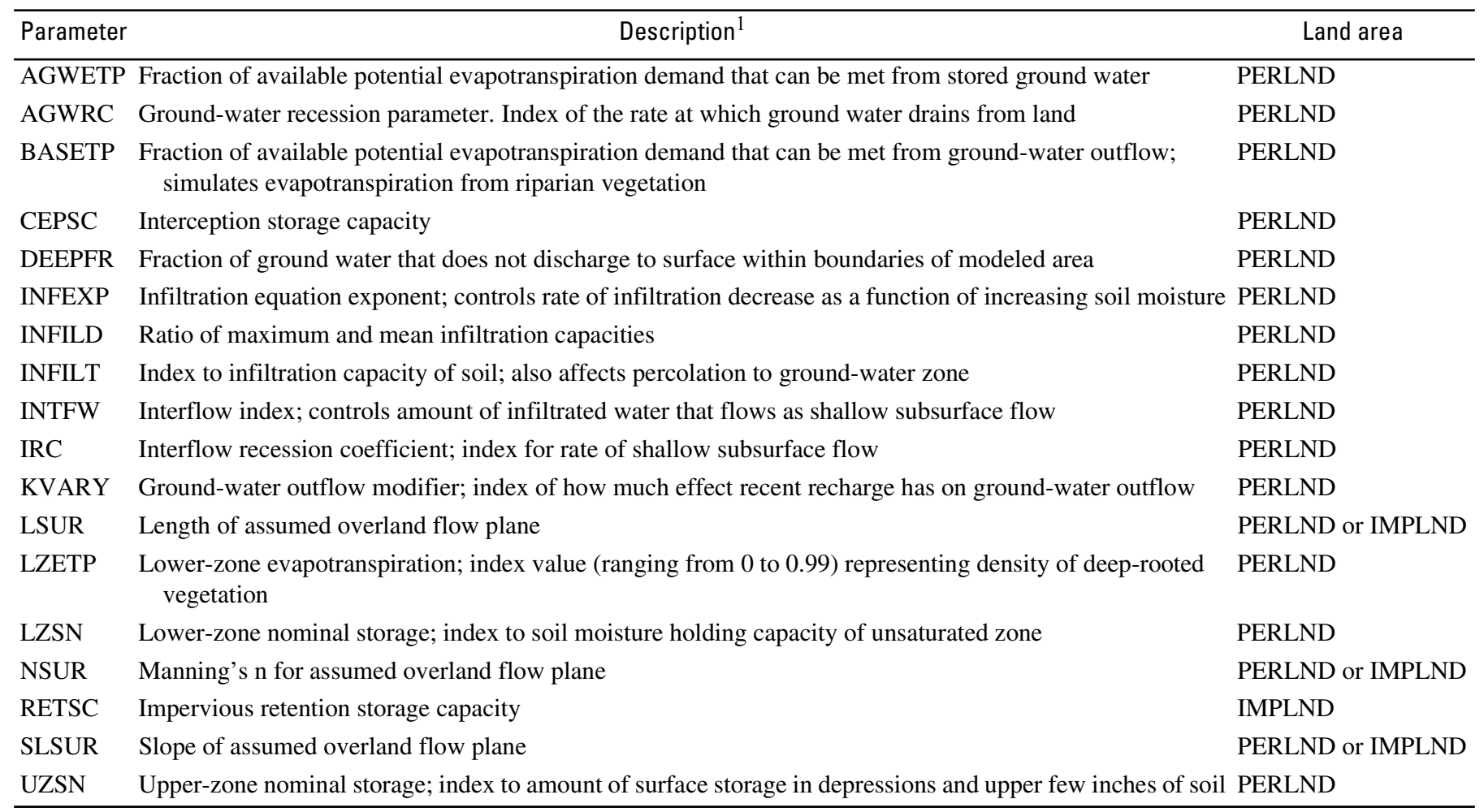

${ }^{1}$ Users manual for Hydrological Simulation Program-FORTRAN (Bicknell and others, 2001) provides a more complete description of each parameter.

\section{Simulation of Streamflow and Estimation of Recharge}

The major steps for simulating streamflow and estimating Edwards aquifer recharge for the study area included data collection and compilation, model development, model calibration and testing, and simulation of streamflow and recharge during 1951-2003.

\section{Data Collection and Compilation}

Input data for the HSPF models include spatial data (land cover, geology-soils, topography, and stream characteristics such as stream-segment length and cross-section dimensions) and meteorologic time-series data (rainfall and pan evaporation). Spatial data were used to develop model hydrologic response units (HRUs) (PERLND [PERvious LaND] and IMPLND [IMPervious LaND], in HSPF terminology). Time series of rainfall, streamflow, and evapotranspiration were used as input for model calibration, testing, and simulations.

Land-cover spatial data were derived from early to mid-1990s satellite data (U.S. Geological Survey, 2003). The resulting land-cover map (fig. 2) comprises nine land-cover categories.

Geology is based on that of Maclay (1995) and Small and Clark (2000). Watershed topography was obtained from USGS 7.5-minute digital elevation model (DEM) files (U.S. Geological Survey, 2001). The DEMs also were used to delineate subbasins as part of the model construction. Channel characteristics

Table 2. Basin-related model parameters for the Hydrological Simulation Program-FORTRAN.

[PERLND, pervious segment; IMPLND, impervious segment, FTABLE, table of depth, surface area, volume, and discharge for each stream reach]

\begin{tabular}{lll}
\hline Parameter & \multicolumn{1}{c}{ Description } & \multicolumn{1}{c}{ Units } \\
\hline AREA & $\begin{array}{l}\text { Drainage area of each PERLND } \\
\text { or IMPLND }\end{array}$ & Acres \\
LEN & Stream reach length & Miles \\
DEPTH & FTABLE depth & Feet \\
SAREA & FTABLE surface area & Acres \\
VOL & FTABLE volume & Acre-feet \\
DISCH & FTABLE discharge & Cubic feet per \\
& & second \\
\hline
\end{tabular}




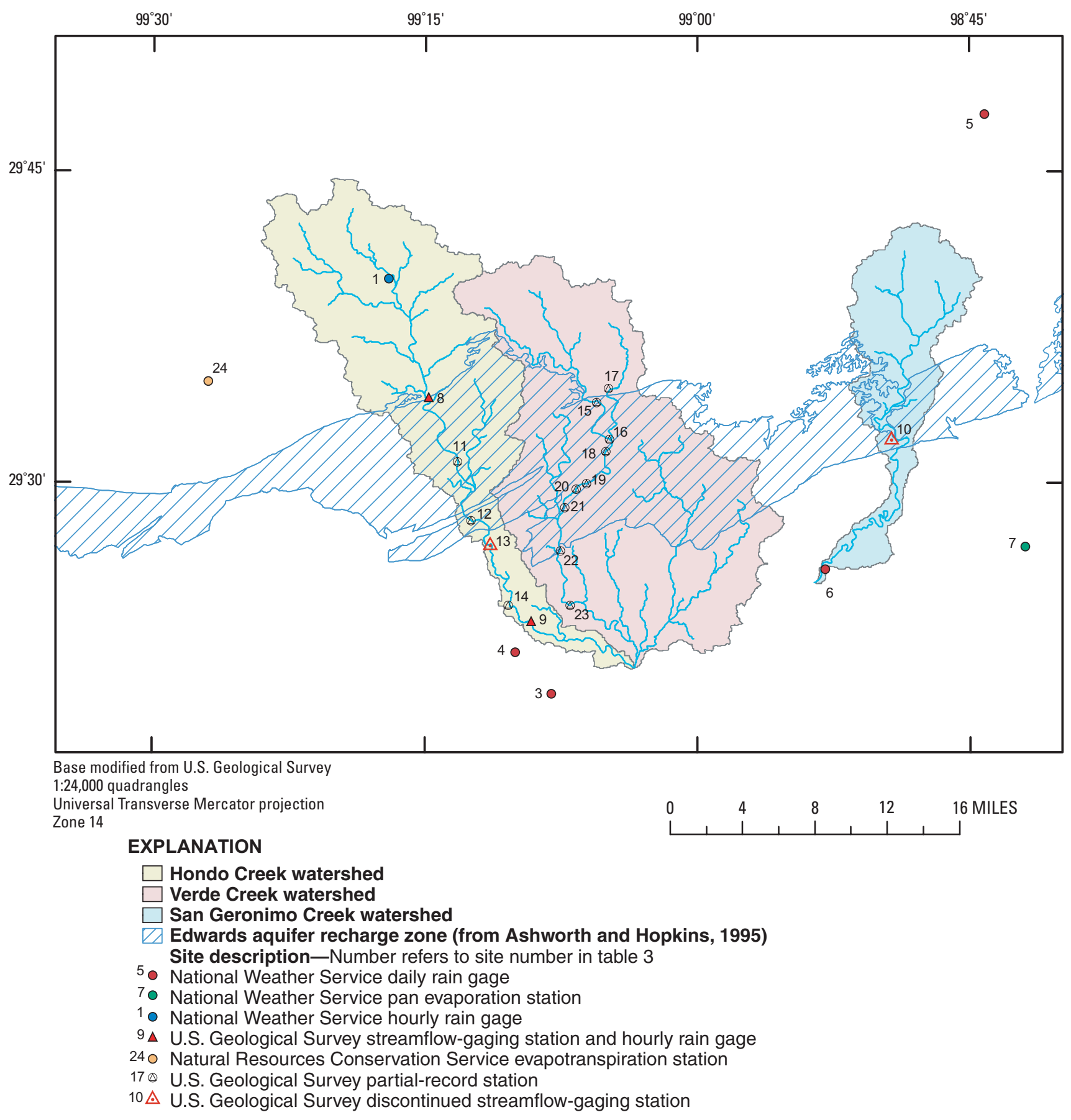

Figure 4. Location of data-collection sites used for Hydrological Simulation Program—FORTRAN (HSPF) model calibration, testing, and simulations, Hondo Creek, Verde Creek, and San Geronimo Creek watersheds, south-central Texas.

for each segment (surface area, volume, and discharge as a function of depth) also were determined from DEM files using geographic information system tools available through the Watershed Modeling System software (U.S. Army Corps of Engineers, Coastal and Hydraulic Laboratory, 2004).

Meteorologic data compiled and used as input to the watershed models included rainfall and pan evaporation data. Data- collection sites are shown in figure 4. Station information for each data-collection site identified in figure 4 is listed in table 3 . Five rain gages were used as the primary source of rainfall data to the models (sites 1, 4, 5, 6, and 8 in fig. 4 and table 3 ).

Because some of the gages were not in operation during the entire study period (1992-2003), data from three additional sites (2, 3, and 6a in table 3$)$ also were used. Because hourly 
Table 3. Data-collection stations used for Hydrological Simulation Program—FORTRAN model input, calibration, and simulations for Hondo Creek, Verde Creek, and San Geronimo Creek watersheds, south-central Texas.

[dd, degrees; mm, minutes; ss, seconds; NWS, National Weather Service; --, unknown; USGS, U.S. Geological Survey; CR, County Road; FM, Farm Road; SH, State Highway, NRCS, Natural Resources Conservation Service]

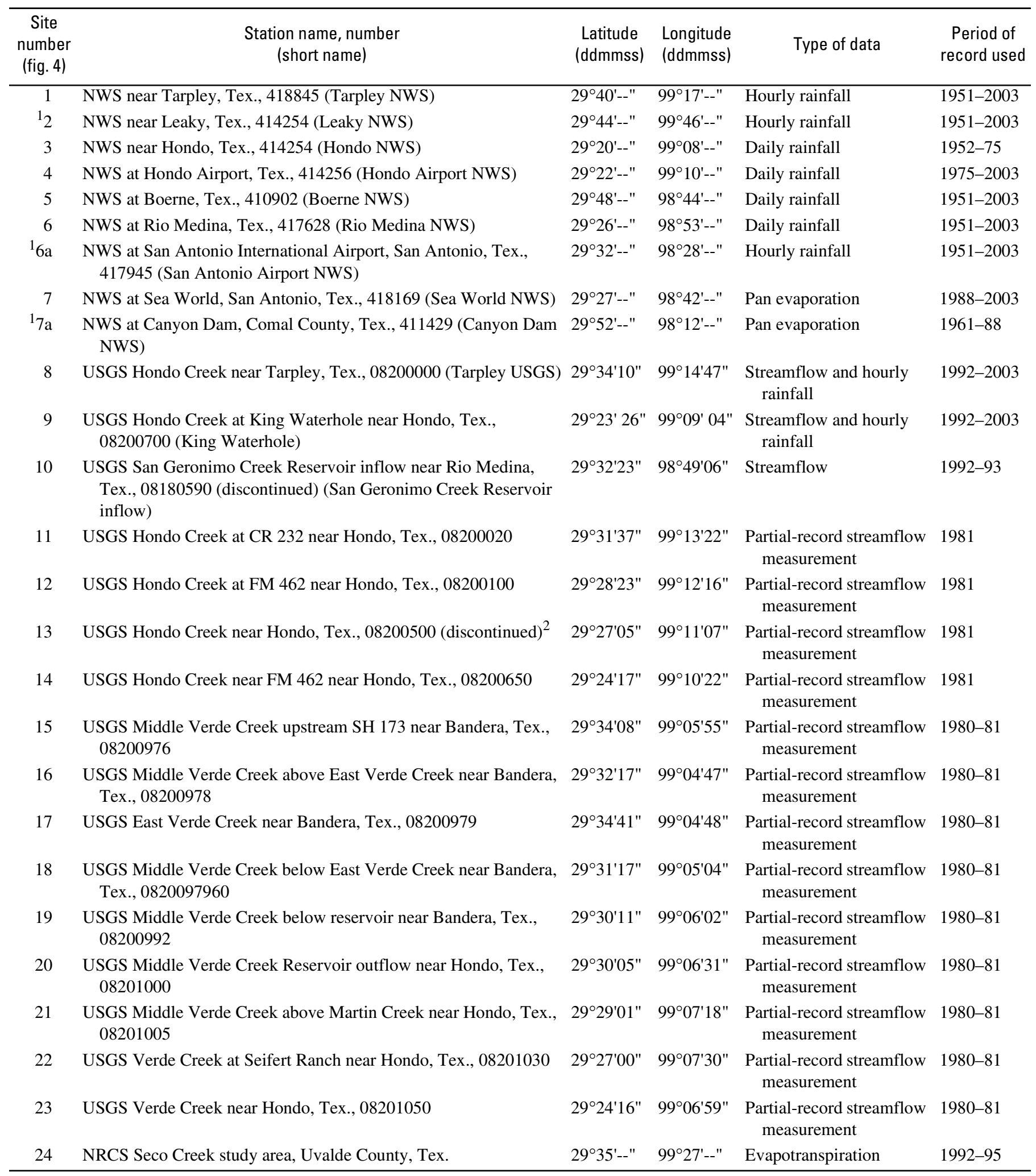

\footnotetext{
${ }^{1}$ Not shown in figure 4 .

2 Streamflow 1951-64.
} 
Table 4. Sources of rainfall data used to provide missing record and time-step disaggregation for primary rainfall time series used in the Hydrological Simulation Program—FORTRAN (HSPF) model, Hondo Creek, Verde Creek, and San Geronimo Creek watersheds, southcentral Texas.

[NWS, National Weather Service; USGS, U.S. Geological Survey; --, not used]

\begin{tabular}{|c|c|c|c|c|}
\hline $\begin{array}{c}\text { Primary rain } \\
\text { gage }\end{array}$ & $\begin{array}{c}\text { Period of } \\
\text { record }\end{array}$ & $\begin{array}{c}\text { Data time } \\
\text { step }\end{array}$ & $\begin{array}{l}\text { Gages used to fill } \\
\text { missing data }\end{array}$ & $\begin{array}{l}\text { Gages used for } \\
\text { disaggregation }\end{array}$ \\
\hline Tarpley NWS & $1951-2003$ & Hourly & $\begin{array}{l}\text { Leakey NWS (1951-91); Tarpley USGS } \\
\quad(1992-2003)\end{array}$ & -- \\
\hline Tarpley USGS & $1992-2003$ & Hourly & Tarpley NWS & -- \\
\hline Hondo Airport NWS & $1975-2003$ & Daily & Tarpley NWS & Tarpley NWS, San Antonio Airport NWS \\
\hline Boerne NWS & $1951-2003$ & Daily & Rio Medina NWS & Tarpley NWS, San Antonio Airport NWS \\
\hline
\end{tabular}

rainfall data are preferred for the model simulations, data from NWS daily stations were disaggregated ${ }^{1}$ to hourly data by using the nearest NWS or USGS stations with available hourly data. Information on which gages were used to fill missing record and gages used for dissaggregation is listed in table 4.

Two NWS stations were used as the source of potential evaporation data for the models. The Sea World NWS station at San Antonio (site 7a in table 3) provided data for 1961-88. Average 1988-2003 monthly values of pan evaporation from Sea World were used to estimate evaporation for 1951-60 (the Canyon Dam station began operation in 1961). The NWS daily (monthly, before 1961) pan evaporation data were disaggregated ${ }^{1}$ to hourly rates for each day for model simulations.

Streamflow data for calibrating HSPF streamflow were available for 1992-2003 from two active USGS streamflowgaging stations (fig. 4, table 3). Station 08200000 Hondo Creek near Tarpley monitors streamflow from the upper $95.6 \mathrm{mi}^{2}$ of the watershed; station 08200700 Hondo Creek at King Waterhole near Hondo monitors the upper $149 \mathrm{mi}^{2}$ of the watershed. Station 08200500 Hondo Creek near Hondo, operated during 1953-64, measured streamflow from the upper $132 \mathrm{mi}^{2}$ of the watershed. Verde Creek is ungaged. Supplementary streamflow measurements were made at selected sites on Hondo and Verde Creeks after several storms in 1980 and 1981 (Land and others, 1983) (sites 11-23, fig. 4 and table 3). These measurements were made to help quantify streamflow losses in the Edwards aquifer recharge zone. Data from a discontinued streamflowgaging station on San Geronimo Creek (08180590 San Geronimo Creek Reservoir inflow near Rio Medina) were available for 1992-93.

\section{Model Construction}

HSPF models of the three watersheds were constructed by (1) defining subwatersheds for the watersheds; (2) classifying unique HRUs on the basis of combinations of land cover, geology, and slope; and (3) and determining initial (uncalibrated) values of associated model parameters. Initial parameter estimates were obtained primarily from previous studies (Brown and Raines, 2002; Ockerman, 2002) and secondarily from hydrologic judgment.

The HSPF models were configured by dividing each watershed into subwatersheds (fig. 5) to produce discrete HSPF stream and reservoir segments. Guidelines for developing the stream-segment configuration include defining segments with (1) similar flow travel times that approximate the model simulation time step, (2) homogeneous channel properties, such as slope and conveyance, and (3) outlets of subwatersheds at important points, such as streamflow-gaging stations, reservoirs, outcrop boundaries, and inflows or outflows. The area of each subwatershed is listed in table 5.

Five rain-gage sites provided the primary rainfall inputs to the models. Rainfall data were applied to the model subwatersheds (fig. 6) on the basis of a modified Thiessen distribution (Wanielista, 1990). A single pan evaporation time-series data set (Sea World NWS, fig. 4 and table 3) was applied to the model subwatersheds.

In each subwatershed, pervious and impervious HRUs were classified according to combinations of three factors: geology, land cover, and land slope. Five geology categories are (1) Glen Rose Limestone (Trinity aquifer outcrop), (2) Edwards Group outcrop (Edwards aquifer recharge zone), (3) Edwards Group remnants (hilltops) overlying Glen Rose Limestone, (4) Edwards upper confining units, and (5) alluvial deposits. Land cover was one or more of the eight categories (excluding water) shown in figure 2. Land slopes were classified into three categories: Low slope, 0-5 percent; medium slope, 5-10 percent; and steep slope, greater than 10 percent.

Combinations of geology, land cover, and land slope result in 120 possible unique HRUs, not including impervious land cover. The actual number of HRUs in the models is 111 because some combinations do not exist (for example, alluvial deposits

\footnotetext{
${ }^{1}$ The rainfall and potential evaporation disaggregation programs are part of the BASINS watershed modeling software package (U.S. Environmental Protection Agency, 2003). Daily rainfall is disaggregated according to the temporal rainfall distribution at one or more nearby hourly stations. Daily potential evaporation is distributed on the basis of latitude and time of year.
} 


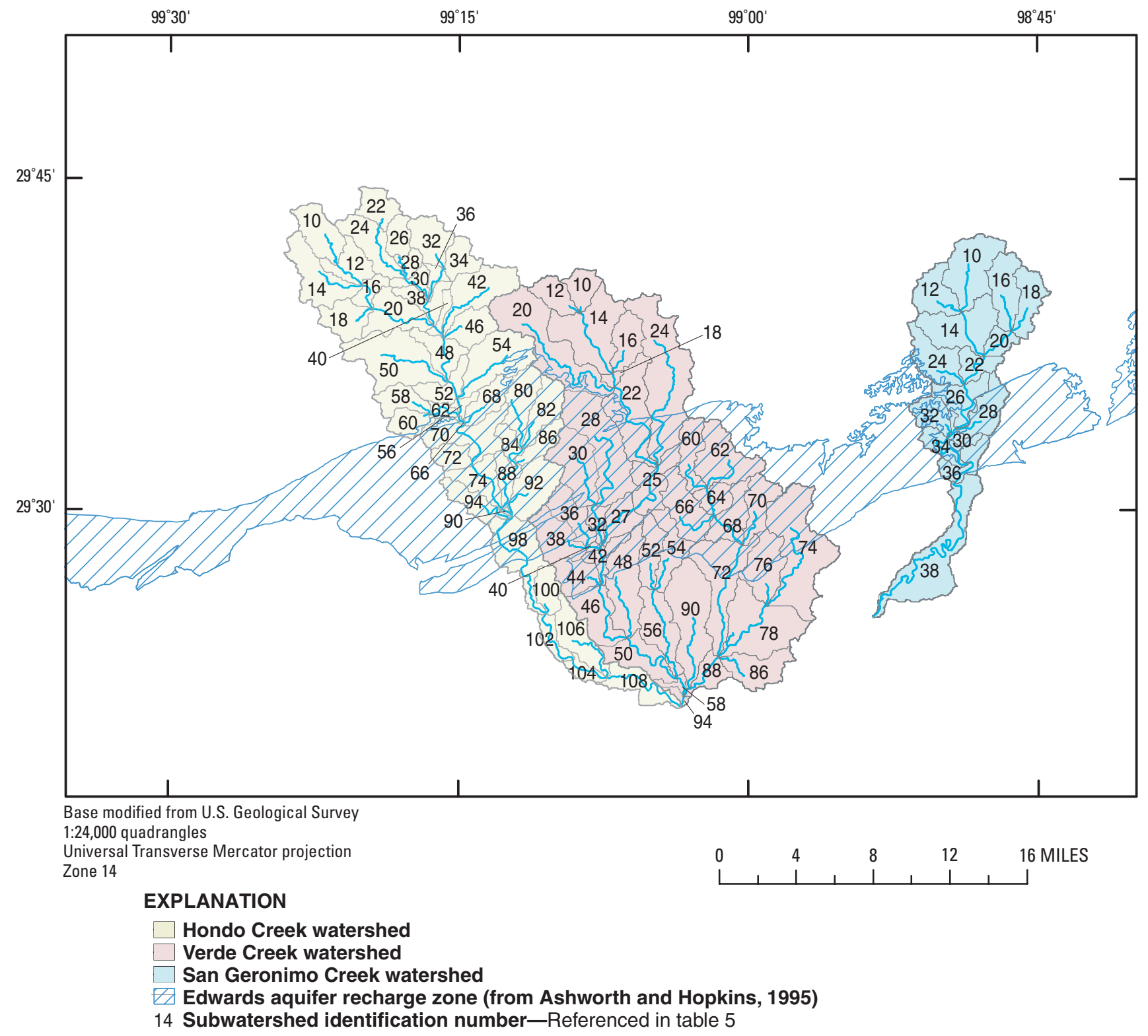

Figure 5. Subwatersheds in Hondo Creek, Verde Creek, and San Geronimo Creek watersheds, south-central Texas, for Hydrological Simulation Program-FORTRAN (HSPF) model development.

on steep slopes). In HSPF teminology, HRUs correspond to PERLND and IMPLND segments.

In each watershed, substantial amounts of runoff are lost to streamflow channel infiltration (recharge) as the creeks flow across the Edwards aquifer recharge zone. HSPF does not include process parameters or specific features to account for natural streamflow losses. Instead, these losses are simulated as water withdrawals from each stream segment. The withdrawals are specified in the stream segment (FTABLE) configuration as a function of streamflow. The relation between streamflow losses and streamflow for a specific channel segment/watershed is based on gain-loss measurements made by Land and others (1983) at selected sites along Hondo and Verde Creeks. Additional streamflow measurements were made on Hondo Creek in June 2004 (Aragon Long and others, 2005).

Model construction was completed by assigning initial values to process-related HSPF parameters. These values represented a starting point for calibration of the models by trial-and-error parameter adjustment. Initial values of parameters related to streamflow and recharge were based on previous HSPF studies in the region (Brown and Raines, 2002; Ockerman, 2002). 


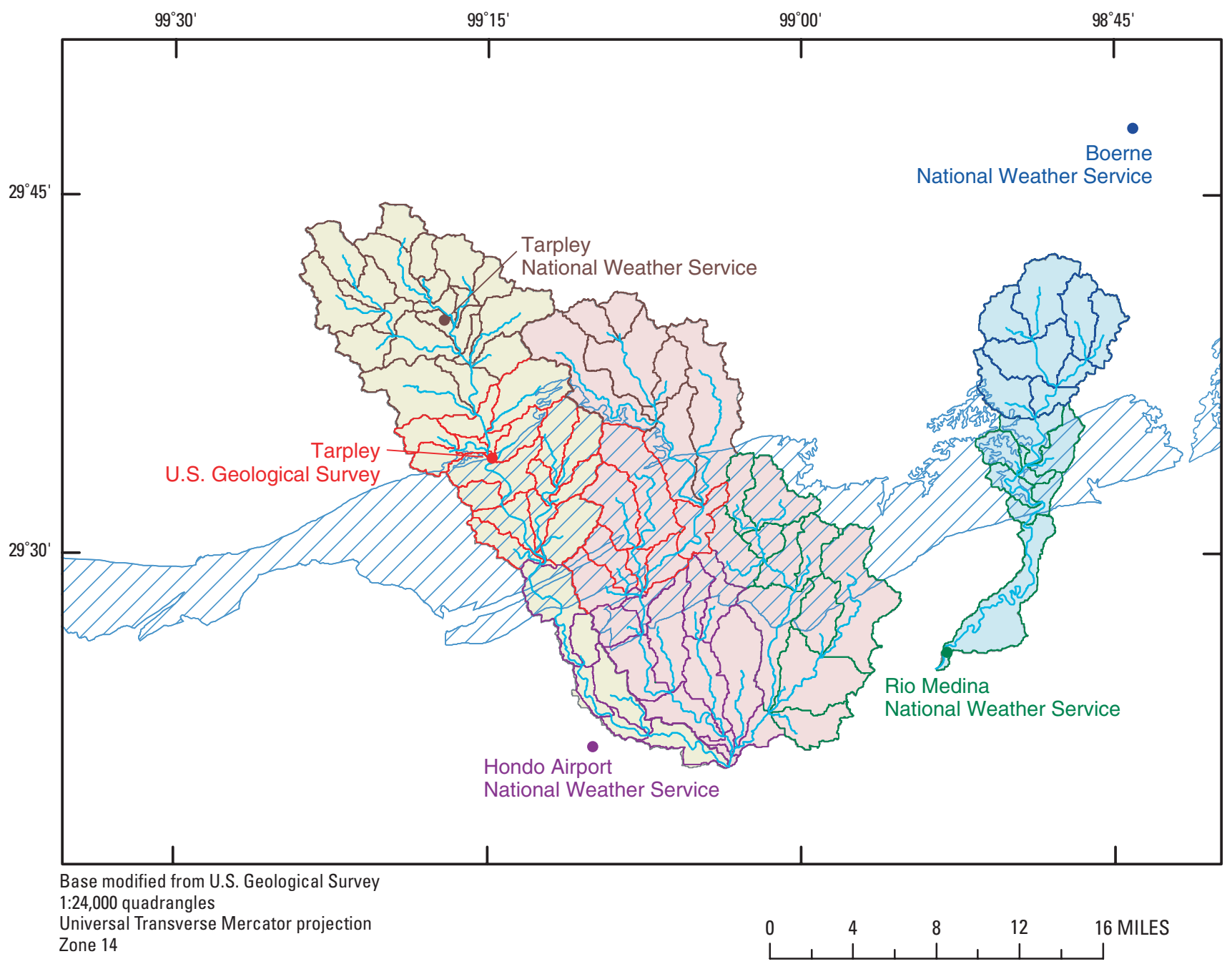

\section{EXPLANATION}

Hondo Creek watershed

Verde Creek watershed

San Geronimo Creek watershed

Edwards aquifer recharge zone (from

Ashworth and Hopkins, 1995)
Boundary of subwatershed by rainfall area for HSPF model Hondo Airport National Weather Service Rio Medina National Weather Service

Tarpley National Weather Service Tarpley U.S. Geological Survey Boerne National Weather Service

Rain gage and name-Color corresponds to associated rainfall area

National Weather Service

\section{Boerne}

Figure 6. Primary rain gages and associated rainfall areas for Hydrological Simulation Program—FORTRAN (HSPF) model calibration, testing, and simulations, Hondo Creek, Verde Creek, and San Geronimo Creek watersheds, south-central Texas.

\section{Model Calibration and Testing}

\section{Streamflow}

A primary goal of watershed-model calibration is to match simulated streamflow to actual streamflow measured at a gaging station. Two long-term USGS streamflow-gaging stations are in the Hondo Creek watershed; no long-term stations are in the Verde Creek and San Geronimo watersheds. The model was calibrated according to the guidelines of Donigian and others (1984) and Lumb and others (1994). Calibration generally involved adjusting the process-related parameter values to improve the model fit-that is, the match between simulated and measured streamflow. Criteria such as error in total streamflow volume for the calibration period, low-flow and high-flow 
Table 5. Subwatershed drainage areas, Hondo Creek, Verde Creek, and San Geronimo Creek watersheds, south-central Texas.

[ID, identification number; --, not applicable]

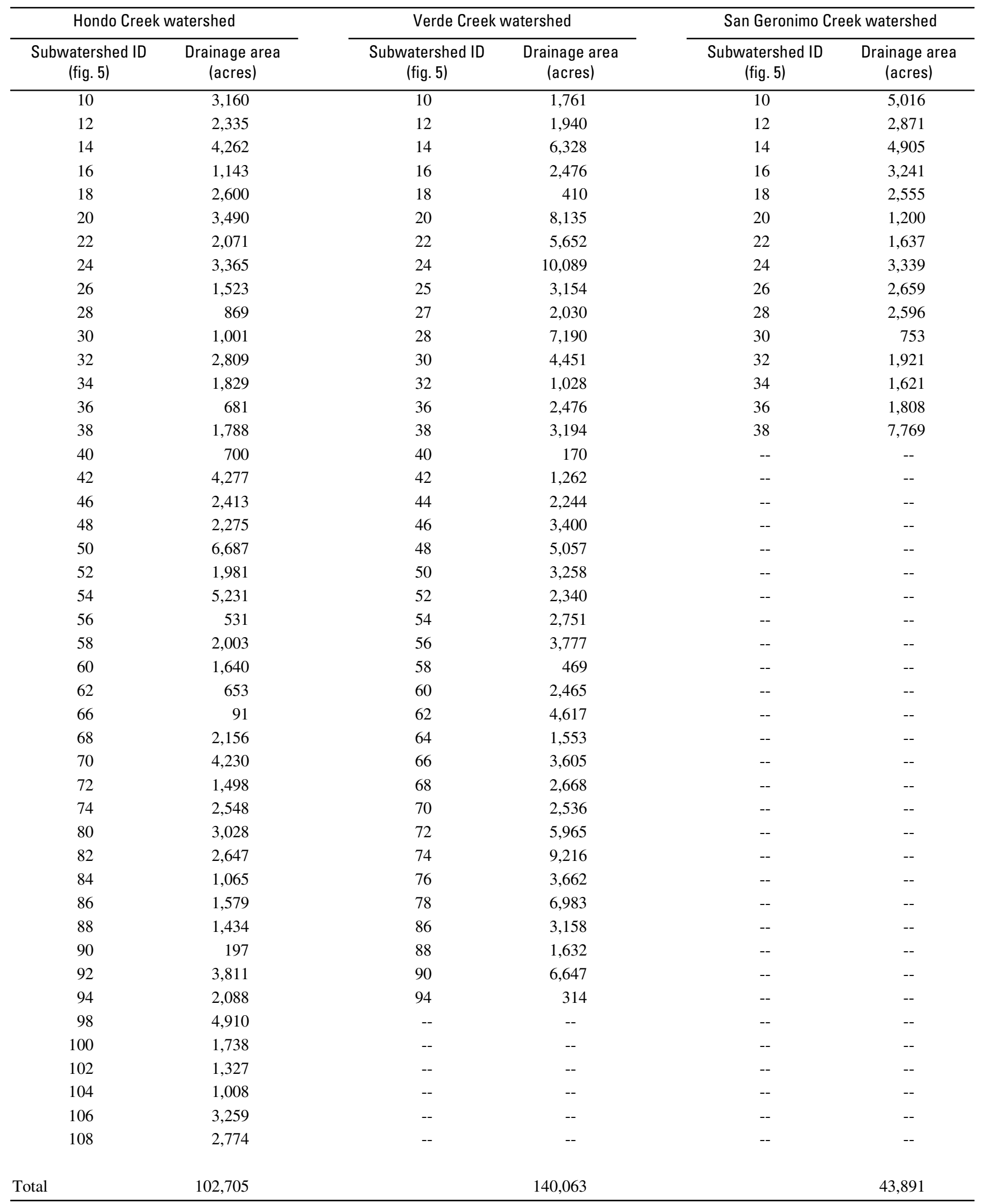


distribution, and error in peak flows were used to evaluate how well simulated streamflow matched measured streamflow. Because most process-related parameters cannot be measured directly, they are specified through iterative calibration.

Model basin-related parameter values were computed from available spatial data, to the extent possible. For example, average slopes of PERLNDS were computed from digital elevation data.

\section{$\underline{\text { Hondo Creek Model }}$}

The Hondo Creek model was calibrated for the period January 1, 1992, to December 31, 1999, using an hourly time step. The response of the calibrated model was further tested using data for the period January 1, 2000, to December 31, 2003. Data from USGS streamflow-gaging station 08200000 Hondo Creek near Tarpley were used to calibrate model streamflow for the Hondo Creek watershed upstream from the gage (subwatersheds 10-66). Data from USGS streamflow-gaging station 08200500 Hondo Creek at King Waterhole near Hondo were used to calibrate subwatersheds 68-102. Calibrated parameters for PERLND and IMPLND HRUs in subwatersheds 68-102 were transferred to the lower, ungaged subwatersheds (104-108).

Streamflow calibration and testing results for Hondo Creek near Tarpley and Hondo Creek at King Waterhole near Hondo are listed in table 6. The measured and simulated streamflow and percentage differences are reported for total flow volume, highest 10 percent of daily flow volumes, lowest 50 percent of daily flow volumes, and selected storm peaks. Storm peaks included in the analyses are all measured peaks greater than 1,000 cubic feet per second $\left(\mathrm{ft}^{3} / \mathrm{s}\right)$. There were 24 such streamflow peaks at the Tarpley station and 16 peaks at the King Waterhole station.

Two model-fit statistics were used to examine the quality of the model fit on an annual, monthly, daily, and hourly basis: (1) the coefficient of determination of the linear regression between measured and simulated streamflow, which provides a measure of the variance between measured and simulated streamflows explained by the regression-in other words, a rough measure of the goodness of fit of the regression; and (2) the coefficient of model-fit efficiency (Nash and Sutcliffe, 1970), which indicates how well the graph of simulated streamflow as a function of measured streamflow matches the line of equal value (Knapp and others, 2004). Thus model-fit efficiency is a measure of the match between measured and simulated streamflows.

Error in simulated total flow volume at the Tarpley gage for the calibration period (1992-99) was 0. Simulated annual flow volume for the testing period (2000-2003) exceeded measured annual flow volume by 2.7 percent. For the entire 1992-2003 period, simulated total flow volume exceeded the measured amount by 1.1 percent. Error in simulated total flow volume at the King Waterhole gage for the calibration period (1992-99) was 1.0 percent; for the testing period, 3.9 percent; and for the entire period, 1.1 percent.
Simulation errors for other criteria generally are within acceptable limits (compared to default criteria guidelines of HSPEXP [Lumb and others, 1994]). During the testing period (2000-2003), simulated lowest 50 percent of daily flow volumes at the Tarpley gage was 11.1 percent greater than measured flows. For the entire calibration and testing period the lowest 50 percent of simulated daily flow volumes was 2.6 percent greater than measured flows. Both Hondo Creek gages were rendered inoperative during a July 2002 flood, and daily mean streamflows at both sites were estimated (A.M. Miller, U.S. Geological Survey, oral commun., 2004). The July 2002 flood accounted for about 90 percent of the total streamflow volume at the King Waterhole gage during the 2000-2003 period. So, potential error in the estimates of gaged streamflow might affect the comparison statistics listed in table 6 (at end of report).

Simulated flows at both USGS gages were evaluated by graphical comparison of measured and simulated daily time series, exceedance-probability curves, and scatter plots (figs. 7, 8). General agreement between the measured and simulated exceedance-probability curves indicates adequate calibration over the range of flow conditions.

Donigian and others (1984) present general guidelines for characterizing HSPF calibrations. For annual and monthly runoff volumes, model calibration is considered very good when the error is less than 10 percent, good when the error is 10 to 15 percent, and fair when the error is 15 to 25 percent. By these guidelines, calibration results for annual flow volumes at both gages are very good. Coefficients of determination and modelfit efficiency near or above 0.9 indicate an acceptable match between measured and simulated streamflows. By this criterion, annual, monthly, and daily simulated streamflows adequately matched measured values, but simulated hourly streamflows did not.

\section{Verde Creek Model}

Process-related parameters from the calibrated Hondo Creek model were applied to the Verde Creek watershed to produce the Verde Creek model. Discrete discharge measurements made along Verde Creek in 1981 (Land and others, 1983) were used to help develop streamflow channel infiltration capacity for the FTABLEs of all models. No other streamflow data from Verde Creek were used to calibrate or test the Verde Creek model. Because the accuracy of the Verde Creek model is uncertain, results are not provided in this report.

\section{San Geronimo Creek Model}

Process-related parameters from the calibrated Hondo Creek model were applied to the San Geronimo Creek watershed to produce the San Geronimo Creek model. To assess the validity of using parameters from the Hondo Creek model in the San Geronimo Creek model, the simulated streamflow was compared to measured streamflow from a discontinued USGS streamflow-gaging station (San Geronimo Creek Reservoir 

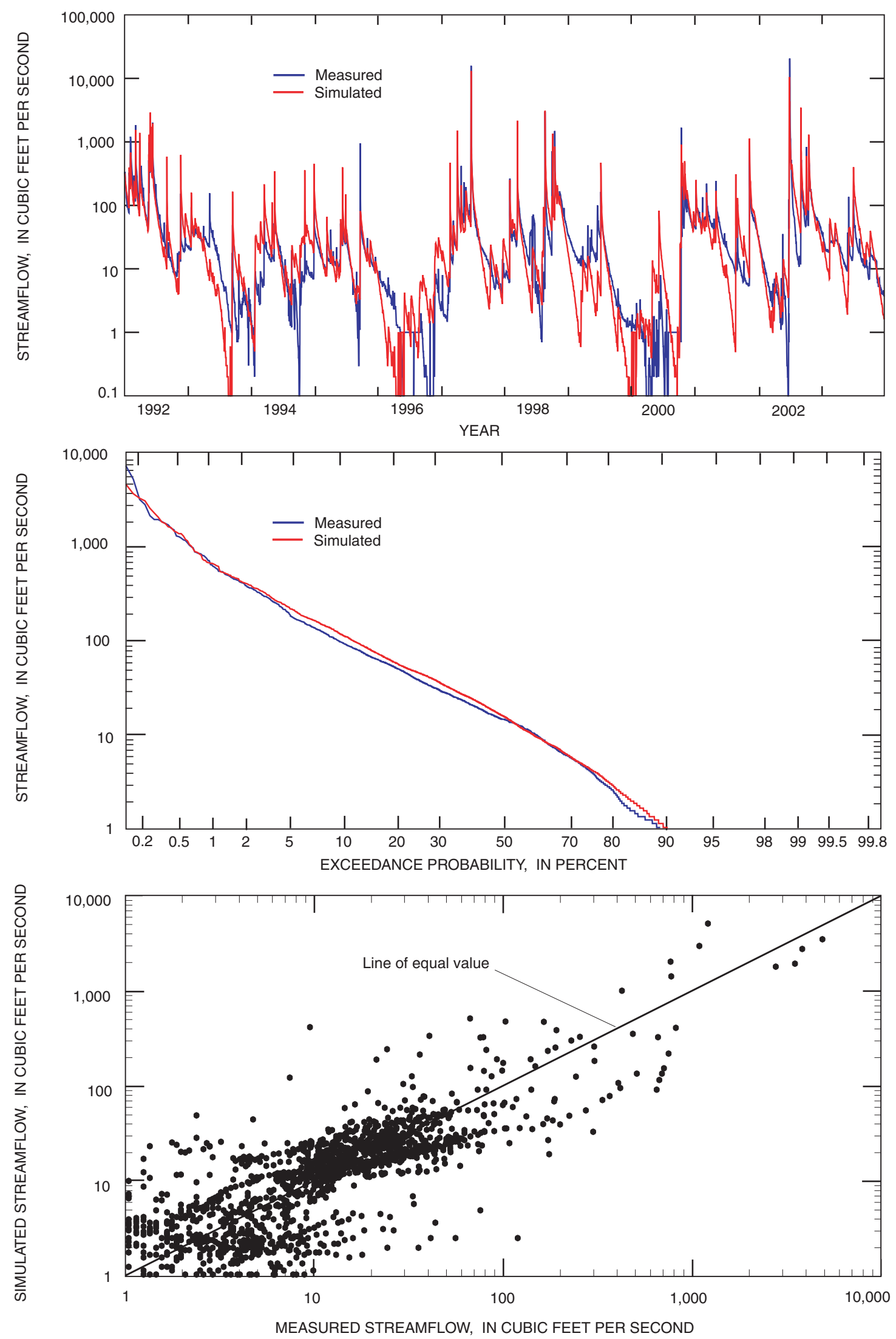

Figure 7. Measured and simulated daily mean streamflow at U.S. Geological Survey streamflow-gaging station 08200000 Hondo Creek near Tarpley, Texas, 1992-2003. 

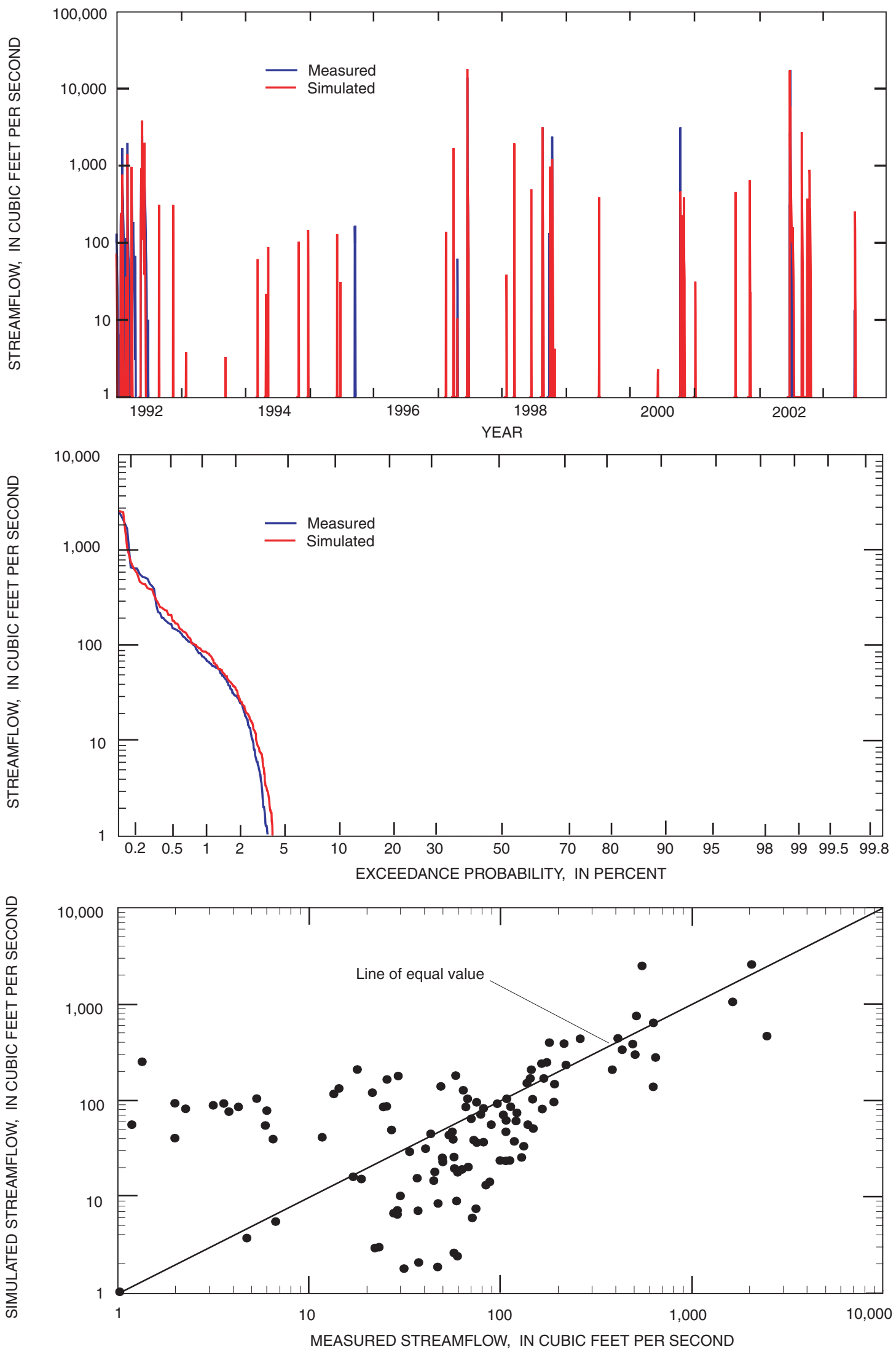

Figure 8. Measured and simulated daily mean streamflow at U.S. Geological Survey streamflow-gaging station 08200700 Hondo Creek at King Waterhole near Hondo, Texas, 1992-2003. 
inflow, site 10 in fig. 4, table 3) during 1992-93. The comparison is summarized in table 7 (at end of report). Generally, simulated volumes and peak flows were higher than measured flows. Simulated flow volume (43,600 acre-ft) during 1992-93 was 31.7 percent greater than measured flow volume $(33,100$ acre-ft). Simulated storm peaks (three measured peaks that exceeded $1,000 \mathrm{ft}^{3} / \mathrm{s}$ ) exceeded measured peaks by 77.9 percent.

Because a substantial part of recharge to the Edwards aquifer occurs as infiltration of flow in the stream channel, simulated streamflow that exceeds measured streamflow in San Geronimo Creek likely results in overestimation of recharge. Therefore, on the basis of 1992-93 streamflow data from the San Geronimo Creek watershed, the model was recalibrated by adjusting selected process-related parameters, primarily INFILT and LZSN (table 1). Channel-loss characteristics in the FTABLEs also were adjusted. The simulation results after recalibration are shown in figure 9 and table 7.

The resulting simulated total flow volume and the highest 10 percent ( 1.9 percent error) and lowest 50 percent $(0$ percent error) of daily flow volumes are close to measured data. Coefficients of determination and model-fit efficiency indicate an acceptable match between measured and simulated annual and monthly streamflows. However, coefficients of determination and model-fit efficiency are low (compared to those of the Hondo Creek simulations) for daily and hourly simulations. Therefore, the model calibration for daily and hourly simulations is relatively poor. One factor that affects the calibration is few available streamflow data from San Geronimo Creek.

Because streamflow is intermittent at the measurement site, few discharge measurements were made during the 1992-93 datacollection period to develop and confirm the stage-discharge rating (the relation between measured water stage and computed discharge). Also, gain-loss measurements, similar to the measurements made along Hondo and Verde Creeks to estimate streamflow infiltration, have not been made along San Geronimo Creek.

\section{Evapotranspiration}

In addition to streamflow calibration, another goal of watershed-model calibration is to accurately simulate the overall water budget in the watershed, which includes recharge and evapotranspiration (ET). Model simulations of recharge cannot be compared to measured values because diffuse recharge (direct infiltration of rainfall through the soil layers to the water table), especially within the faulted karst environments of the study-area watersheds, cannot be measured directly. Estimates of recharge therefore depend on accurate model representations of the remaining water-budget components not associated with recharge (streamflow, ET, and changes in soil-water storage over the simulation period). Annual streamflow in Hondo Creek (King Waterhole streamflow-gaging station) usually is less than 10 percent of rainfall. Changes in soil-water storage (over long simulation periods) are relatively small. Therefore, ET plus recharge likely accounts for about 90 percent of rainfall. Maclay (1995, p. 31) reports that evapotranspiration in the area is about 85 to 90 percent of rainfall. Uncertainty in ET simulations can result in considerable potential error in diffuse recharge estimates.

HSPF process parameters related to ET simulation were not calibrated with actual data because very few measured ET data are available for the region, and no ET data have been collected in the study area. ET-related parameter values from other HSPF models (Brown and Raines, 2002; Ockerman, 2002) were used to guide selection of those parameters for the Hondo Creek model. Also, parameters that affect ET also affect streamflow and are adjusted during the streamflow calibration. To test the validity of the ET simulations, only general comparisons with few available data were possible. The simulated average annual ET values from several PERLND categories are listed in table 8 (at end of report).

For the three land categories listed in table 8 , average 1992-2003 ET ranged from 77 to 89 percent of rainfall. Annual ET showed greater variability, ranging from 54 to 115 percent of annual rainfall.

Probably the best-available ET data for comparison were collected during 1991-95 by the Natural Resources Conservation Service in the Seco Creek watershed (site 24, fig. 4 and table 3) adjacent to the Hondo Creek watershed in northeastern Uvalde County (Dugas and others, 1998). Average ET rates in the Seco Creek watershed during March through October were 0.075 inch per day (in/d). HSPF simulations for the Hondo Creek watershed during the same time period and with similar land cover (Glen Rose Limestone, medium slope, evergreen forest) yielded an average daily ET rate of $0.079 \mathrm{in} / \mathrm{d}$. Compared to the Seco Creek measured ET, the HSPF simulated ET is considered reasonable.

\section{Summary of HSPF Process-Related Parameters}

Through calibration and testing, sets of process-related parameters were developed for the Hondo Creek, Verde Creek, and San Geronimo Creek watershed models. The processrelated annual parameters for the Hondo Creek and Verde Creek models are listed in table 9 (at end of report). The process-related annual parameters for the San Geronimo Creek model are listed in table 10 (at end of report). Values of the monthly varying lower-zone evapotranspiration parameter (LZETP) for all three models are listed in table 11 (at end of report).

\section{Streamflow, 1951-2003}

The results of streamflow simulations (average annual streamflow volumes) for each watershed model are listed in table 12 (at end of report). Total streamflow for a watershed includes all surface runoff, interflow, and base flow that originates in the watershed and reaches the stream channel. Because 

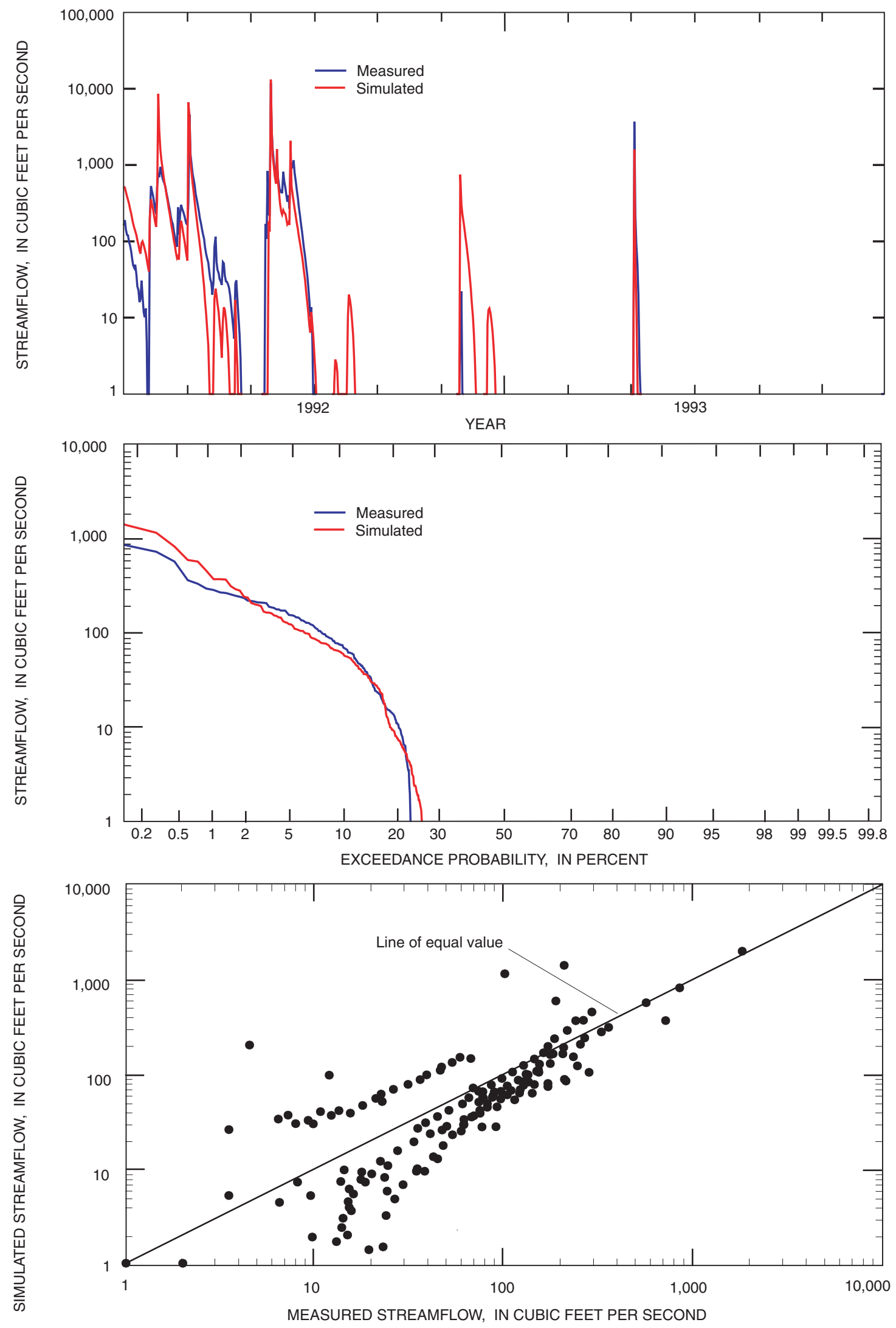

Figure 9. Measured and simulated daily mean streamflow at U.S. Geological Survey streamflow-gaging station 08180590 San Geronimo Creek Reservoir inflow near Rio Medina, Texas, 1992-93. 
of streamflow channel infiltration, much of the total streamflow is lost to recharge before it reaches the watershed outlet. Simulated average annual total streamflow for 1951-2003 in the Hondo Creek, Verde Creek, and San Geronimo Creek watersheds is 45,400; 32,400; and 11,100 acre-ft; respectively. Simulated average annual streamflow at the respective watershed outlets is 13,$000 ; 16,200$; and 6,920 acre-ft; the difference between total streamflow and streamflow at the watershed outlet is streamflow lost to channel infiltration.

Model simulations also were done to assess the effects on streamflow of recharge-enhancement structures completed for Verde Creek in April 1978 and for San Geronimo Creek in November 1979. The recharge-enhancement structures divert streamflow to recharge. Three simulations were done for each of the two watersheds: (1) for 1951-2003 for actual conditions, which means with the structures simulated in the Verde Creek watershed beginning in April 1978 and in the San Geronimo watershed beginning in November 1979; (2) for 1951-2003 without the structures simulated in either watershed for the entire period; and (3) for 1951-2003 with the structures simulated in both watersheds for the entire period.

For Verde Creek simulation (1) streamflow at the watershed outlet was 16,200 acre-ft. Simulations (2) and (3) resulted in average annual streamflow of 16,800 and 15,700 acre-ft, respectively. So, simulation with the recharge-enhancement structure in place during 1951-2003 for the entire period resulted in a reduction of streamflow exiting the watershed of about 6.5 percent.

For San Geronimo Creek simulation (1), streamflow at the watershed outlet was 6,920 acre-ft. Simulations (2) and (3) resulted in average annual runoff of 7,680 and 6,160 acre-ft, respectively. So, simulation with the recharge-enhancement structure in place during 1951-2003 for the entire period resulted in a reduction of streamflow exiting the watershed by about 20 percent. The drainage area above the San Geronimo Creek recharge-enhancement structure is about 78 percent of the watershed (compared to about 29 percent of the Verde Creek watershed upstream from the Verde Creek structure). So, as might be expected, the effect of the Verde Creek structure on streamflow at the watershed outlet is not as great as the effect of the San Geronimo Creek structure.

\section{Recharge, 1951-2003}

The HSPF models for the Hondo Creek, Verde Creek, and San Geronimo Creek watersheds were used to estimate Edwards aquifer recharge during 1951-2003. Annual recharge estimates (simulated recharge) by watershed are listed in table 13 (at end of report). Recharge comprises direct infiltration of rainfall (diffuse recharge) and infiltration of streamflow within the stream channels. Most of the simulated streamflow channel infiltration occurs in the recharge zone, but some occurs downstream from the recharge zone (about 5 percent in
Hondo Creek, about 0.5 percent in Verde Creek, and about 9 percent San Geronimo Creek). The recharge estimates in table 13 do not include channel infiltration downstream from the recharge zone, and they do not include estimates of subsurface inflow to the Edwards aquifer from other aquifers.

For the Hondo Creek watershed, estimated average annual recharge for 1951-2003 is 37,900 acre-ft/yr, or 5.04 inches (in.) (about 17 percent of average annual rainfall). Most of the recharge $\left(82\right.$ percent $\left.^{2}\right)$ occurred as streamflow channel infiltration. About 18 percent occurred as diffuse recharge, or direct infiltration of rainfall to the aquifer. Annual Hondo Creek recharge is highly variable (depending on annual rainfall), ranging from 1,920 acre- $\mathrm{ft}$ (0.26 in.) in 1956 to 117,000 acre-ft (15.6 in.) in 1992.

For the Verde Creek watershed, estimated average annual recharge for 1951-2003 is 26,000 acre-ft/yr, or $3.36 \mathrm{in}$. (about 11 percent of average annual rainfall). About 62 percent $^{2}$ of the recharge occurred as streamflow channel infiltration. About 38 percent occurred as diffuse recharge. Annual Verde Creek recharge varied from 1,760 acre-ft (0.23 in.) in 1956 to 73,800 acre-ft (9.54 in.) in 1992.

For the San Geronimo Creek watershed, estimated average annual recharge for 1951-2003 is 5,940 acre-ft/yr, or $1.97 \mathrm{in.}$ (about 6 percent of average annual rainfall). About 64 percent $^{2}$ of the recharge occurred as streamflow channel infiltration. About 36 percent occurred as diffuse recharge. Annual San Geronimo Creek recharge varied from 100 acre-ft (0.03 in.) in 1954 to 26,700 acre-ft (8.87 in.) in 1992.

Average annual recharge estimates from the San Geronimo Creek model before and after recalibration with measured streamflow data were compared to assess the sensitivity of the recharge estimation to streamflow calibration. During 1992-93 (period when streamflow calibration data were available) the simulated runoff volume exiting the San Geronimo Creek watershed before recalibration, using process-related parameters from the calibrated Hondo Creek model (43,600 acre-ft, table 7), was about 32 percent greater than after recalibration $(33,100$ acre-ft, table 7$)$. Before recalibration the simulated average annual (1951-2003) recharge was 6,220 acre-ft/yr, or 2.06 in. This estimate is about 4.7 percent greater than the estimate after recalibration (5,940 acre-ft, table 13). During the period when streamflow calibration data were available (1992-93), the recharge estimate before recalibration was 5.0 percent greater than the estimate after recalibration. So, for the San Geronimo Creek watershed, the recharge estimate was not particularly sensitive to the recalibration.

HSPF 1992-2003 recharge estimates for Hondo Creek and Verde Creek were compared to USGS estimates of recharge made using the Puente method (Puente, 1978; R.N. Slattery, U.S. Geological Survey, written commun., 2003). Because the USGS recharge estimates are annual values, only annual comparisons with HSPF simulations are possible. Estimates of recharge for the San Geronimo Creek watershed by the Puente method are not available because, in the Puente

\footnotetext{
${ }^{2}$ Does not include streamflow channel infiltration downstream from the recharge zone.
} 
method, recharge in that watershed is included in the recharge computation for a larger watershed. Recharge estimates for the Hondo Creek and Verde Creek watersheds for 1992-2003 computed from HSPF simulation and the Puente method are listed in table 14 (at end of report). Overall, for Hondo Creek, the HSPF recharge estimates average 40,100 acre-ft/yr compared to 51,700 acre-ft/yr estimated by the Puente method (about 22 percent less). HSPF recharge estimates for Verde Creek average 28,700 acre-ft/yr compared to 47,700 acre-ft/yr estimated by the Puente method (about 40 percent less). For years of greaterthan-average rainfall in both watersheds, the HSPF recharge estimates are substantially less than the Puente recharge estimates. For years of average or less-than-average rainfall, the relation between estimates from the two methods is mixed in terms of which is greater.

\section{Model Limitations and Assessment}

Errors in model calibration can be classified either as systematic or measurement errors (Raines, 1996). Systematic errors are associated with limitations of the model to represent the hydrologic processes of the study watershed. There are possible limits on how well the model parameters and equations describe the physical characteristics of runoff and recharge. Measurement errors are introduced as a result of inaccurate or missing data. Limitations in the available rainfall data are potentially the most serious source of measurement error for the study. Runoff and recharge in the watershed are highly dependent on the occurrence of relatively extreme storms. The available network of rain gages does not always adequately represent the spatial and temporal variability of rainfall in the watershed.

HSPF model calibration for the three study-area watersheds primarily is based on calibration of HSPF process-related parameters for the Hondo Creek watershed. Process-related parameters obtained from the Hondo Creek calibration were applied directly to the other study watersheds. The Hondo Creek process parameters were applied to the Verde Creek model without recalibration because of a lack of streamflow data for calibration for the Verde Creek watershed. Therefore, the accuracy of streamflow and recharge estimations for the Verde Creek watershed is uncertain. Using Hondo Creek parameter values, the San Geronimo Creek model simulations for 1992-93 did not satisfy calibration criteria. Therefore, the San Geronimo Creek model was recalibrated on the basis of the 1992-93 streamflow data from the San Geronimo watershed.

The Hondo Creek model-fit statistics indicate that streamflow simulations compare well with measured data on an annual, monthly, and daily basis. However, the coefficient of model-fit efficiency for hourly comparisons is low. The model, therefore, is not as effective in predicting hourly streamflow values-for example, peak discharges. However, daily or monthly streamflow volume is predicted with reasonable accuracy and either daily or monthly is likely more important than hourly for estimating recharge because much of the recharge occurs as infiltration of streamflow and because recharge events and processes tend to occur on time scales substantially greater than hourly.

The accuracy of streamflow and recharge estimates from the Verde Creek and San Geronimo Creek models is difficult to assess because of the lack of streamflow data available for model calibration. Transfer of calibrated process-related parameters from the Hondo Creek model to the San Geronimo Creek model resulted in simulations that did not compare favorably with the few measured data. Therefore, using Hondo Creek process-related parameters in the Verde Creek model also might not produce simulations that reasonably represent actual conditions.

Because most recharge to the Edwards aquifer occurs as streamflow infiltration and most of that streamflow originates in the Glen Rose Limestone outcrop upstream from the recharge zone, gaged streamflow upstream from and downstream from the Edwards aquifer recharge zone (similar to that measured in Hondo Creek) might be useful for improving the calibration of the Verde Creek and San Geronimo Creek HSPF models. Additional gain-loss measurements, especially along San Geronimo Creek, also might help improve model calibration. Because ET is a large component of the water budget in these study watersheds, additional ET data, especially in the Edwards aquifer recharge zone, might improve model calibration and estimates of recharge.

\section{Summary}

The U.S. Geological Survey (USGS), in cooperation with the San Antonio Water System, constructed HSPF watershed models to simulate streamflow (runoff) and estimate recharge to the Edwards aquifer in the Hondo Creek, Verde Creek, and San Geronimo Creek watersheds in south-central Texas. The models were calibrated and tested with available data collected during 1992-2003. Simulations of runoff and recharge to the Edwards aquifer were done for 1951-2003.

Outcropping rocks in the upper part of each watershed are Glen Rose Limestone; outcropping rocks in the central part of each watershed - the Edwards aquifer recharge zone-are Edwards Group. Glen Rose Limestone generally has low permeability compared to rocks of the Edwards Group. Edwards Group rocks are characterized by high permeability because of faults, sinkholes, and other karst features. Relatively impermeable confining units overlie the Edwards aquifer south of the recharge zone, the lower part of each watershed. Streams in the study-area watersheds originate in the topographically rugged Texas Hill Country north of the recharge zone and generally flow south, crossing the recharge zone and continuing onto Edwards aquifer confining units.

Two USGS streamflow-gaging stations on Hondo Creek provided adequate data to calibrate the HSPF model of the Hondo Creek watershed. However, suitable calibration data for the Verde Creek and San Geronimo Creek watersheds is 
lacking. Verde Creek is ungaged. Data from the San Geronimo Creek watershed is limited to streamflow data from a discontinued USGS streamflow-gaging station operated during 1992-93.

The approach to develop the models was to first calibrate the Hondo Creek model (with an hourly time step) using 1992-99 data and test that model using 2000-2003 data. Then the calibrated Hondo Creek model parameters were applied to the Verde Creek and San Geronimo Creek watersheds. For the entire calibration and testing period (1993-2003), the simulated total flow volumes for Hondo Creek exceeded measured flow volumes at both USGS gages by about 1.1 percent, within limits considered acceptable for calibration. Two other measures of simulation quality, coefficients of determination and model-fit efficiency, indicate (by values of 0.9 or greater) that annual, monthly, and daily simulated streamflows for Hondo Creek adequately matched measured values, but simulated hourly streamflows did not.

The Verde Creek model, using parameters from the Hondo Creek model, remains untested. The accuracy of streamflow simulations for Verde Creek thus is uncertain.

After applying the Hondo Creek model parameters to the San Geronimo Creek model, the simulation was tested using 1992-93 streamflow data from the discontinued USGS gage. Because the simulated streamflow volumes compared poorly to the measured volumes, the San Geronimo Creek model was recalibrated using the 1992-93 data. The streamflow calibration was improved but not to the level of the Hondo Creek model calibration. The resulting simulated total flow volume and the highest 10 percent and lowest 50 percent of daily flow volumes are within 1.9 percent of measured data. Coefficients of determination and model-fit efficiency indicate an acceptable (or nearly so) match between simulated and measured annual and monthly streamflows. However, those coefficients are low (compared to those of the Hondo Creek simulations) for daily and hourly simulations. Therefore, the model calibration for daily and hourly streamflows is relatively poor compared to the Hondo Creek model calibration.

Simulated average annual total streamflow for 1951-2003 in the Hondo Creek, Verde Creek, and San Geronimo Creek watersheds is $45,400,32,400$, and 11,100 acre-ft, respectively. Simulated average annual streamflow at the respective watershed outlets is $13,000,16,200$, and 6,920 acre-ft; the difference between total streamflow and streamflow at the watershed outlet is streamflow lost to channel infiltration.

Estimated average annual Edwards aquifer recharge (direct infiltration of rainfall [diffuse recharge] and channel infiltration) for Hondo Creek, Verde Creek, and San Geronimo Creek for 1951-2003 is 37,900 acre-ft (5.04 in.), 26,000 acre-ft (3.36 in.), and 5,940 acre-ft (1.97 in.), respectively. Most of the recharge (about 77 percent for the three study watersheds together) occurs as streamflow channel infiltration. Diffuse recharge accounts for the remaining 23 percent of recharge.

HSPF 1992-2003 annual recharge estimates for the Hondo Creek and Verde Creek watersheds were compared to USGS estimates of historical annual recharge for those watersheds computed using a method documented in 1978 and referred to as the Puente method. For the Hondo Creek watershed, the HSPF recharge estimates for 1992-2003 average 40,100 acre$\mathrm{ft} / \mathrm{yr}$ compared to 51,700 acre-ft/yr estimated by the Puente method (about 22 percent less). HSPF recharge estimates for the Verde Creek watershed average 28,700 acre-ft/yr compared to 47,700 acre-ft/yr estimated by the Puente method (about 40 percent less). During years of greater-than-average rainfall in both watersheds, the HSPF recharge estimates are substantially less than the Puente recharge estimates. During years of average or less-than-average rainfall, the relation between estimates from the two methods is mixed in terms of which is greater.

\section{References}

Aragon Long, S.C., Reece, B.D., and Eames, D.R., 2005, Water resources data, Texas, water year 2004-Volume 5. Guadalupe River Basin, Nueces River Basin, Rio Grande Basin, and intervening coastal basins: U.S. Geological Survey WaterData Report TX-04-5, 414 p., accessed July 20, 2005, at http://water.usgs.gov/wdr/2004/WDR-TX-04-5/.

Ashworth, J.B., and Hopkins, Janie, 1995, Aquifers of Texas: Texas Water Development Board Report 345, 69 p.

Bicknell, B.R., Imhoff, J.C., Kittle, J.L. Jr., Donigian, A.S., and Johanson, R.C., 2001, Hydrological Simulation ProgramFORTRAN, user's manual for version 12: Research Triangle Park, N.C., U.S. Environmental Protection Agency, National Exposure Research Laboratory, Office of Research and Development, 725 p.

Bomar, G.W., 1995, Texas weather (2d ed.): Austin, University of Texas Press, 275 p.

Brown, D.S., and Raines, T.H., 2002, Simulation of flow and effects of best-management practices in the upper Seco Creek Basin, south-central Texas, 1991-98: U.S. Geological Survey Water-Resources Investigations Report 02-4249, $22 \mathrm{p}$.

Clark, A.K., 2003, Geologic framework and hydrologic features of the Glen Rose Limestone, Camp Bullis Training Site, Bexar County, Texas: U.S. Geological Survey WaterResources Investigations Report 03-4081, 9 p.

Donigian, A.S., Jr., Bicknell, B.R., and Imhoff, J.C., 1995, Hydrological Simulation Program-FORTRAN (HSPF), in Singh, V.P., ed., Computer models of watershed hydrology: Highlands Ranch, Colo., Water Resources Publications, p. 395-442.

Donigian, A.S., Jr., Imhoff, J.C., Bicknell, B.R., and Kittle, J.L., Jr., 1984, Application guide for Hydrological Simulation Program-FORTRAN (HSPF): U.S. Environmental Protection Agency, Environmental Research Laboratory, EPA-600/3-84-065, 177 p.

Dugas, W.A., Hicks, R.A., and Wright, P., 1998, Effect of removal of Juniperus ashei on evapotranspiration and runoff in the Seco Creek watershed: Water Resources Research, v. 34 , no. 6 , p. 1,499-1,506.

Edwards Aquifer Authority, 2004, Hydrologic data report for 2003: San Antonio, Report 04-02, 188 p. 
HDR Engineering, 1998, Trans-Texas water program, west central study area-Phase II Guadalupe-San Antonio River Basin recharge enhancement study feasibility assessment: Austin, Tex., HDR Engineering [variously paged].

Knapp, H.V., Singh, Jaswinder, and Andrew, Karka, 2004, Hydrologic modeling of climate scenarios for two Illinois watersheds: Watershed Science Section, Illinois State Water Survey, Contract report 2004-07, accessed July 20, 2005, at http://www.sws.uiuc.edu/pubdoc/CR/ISWSCR2004-07.pdf

Land, L.F., Boning, C.W., Harmsen, L., and Reeves, R.D., 1983, Streamflow losses along the Balcones fault zone, Nueces River Basin, Texas: U.S. Geological Survey WaterResources Investigations Report 83-4368, 72 p.

Larkin, T.J., and Bomar, G.W., 1983, Climatic atlas of Texas: Texas Department of Water Resources, Limited Printing Report LP-192, 151 p.

Lumb, A.M., McCammon, R.B., and Kittle, J.L., Jr., 1994, Users manual for an expert system (HSPEXP) for calibration of the Hydrological Simulation Program-FORTRAN: U.S. Geological Survey Water-Resources Investigations Report 94-4168, 102 p.

Maclay, R.W., 1995, Geology and hydrology of the Edwards aquifer in the San Antonio area, Texas: U.S. Geological Survey Water-Resources Investigations Report 95-4186, 64 p., 12 pls.

Nash, J.E., and Sutcliffe, J.V., 1970, River flow forecasting through conceptual models-Part 1. A discussion of principles: Journal of Hydrology, v. 10, no. 3, p. 282-290.

Ockerman, D.J., 2002, Simulation of runoff and recharge and estimation of constituent loads in runoff, Edwards aquifer recharge zone (outcrop) and catchment area, Bexar County, Texas, 1997-2000: U.S. Geological Survey WaterResources Investigations Report 02-4241, 31 p.

Owens, M. K., Lyons, Robert, and Kneuper, Charles, 2001, Evaporation and interception water loss from juniper com- munities on the Edwards aquifer recharge area: Uvalde, Tex., Texas Agricultural Experiment Station and Texas Agricultural Extension Service, 9 p.

Puente, Celso, 1978, Method of estimating natural recharge to the Edwards aquifer in the San Antonio area, Texas: U.S. Geological Survey Water-Resources Investigations Report 78-10, 34 p.

Raines, T.H., 1996, Simulation of storm peaks and storm volumes for selected subbasins in the West Fork Trinity River Basin, Texas, water years 1993-94: U.S. Geological Survey Water-Resources Investigations Report 96-4110, 41 p.

Small, T.A., and Clark, A.K., 2000, Geologic framework and hydrogeologic characteristics of the Edwards aquifer outcrop, Medina County, Texas: U.S. Geological Survey WaterResources Investigations Report 00-4195, 10 p., 1 pl.

U.S. Army Corps of Engineers, Coastal and Hydraulics Laboratory, 2004, WMS-Watershed modeling system: accessed April 20, 2004, at http://chl.erdc.usace.army.mil/ CHL.aspx? $\mathrm{p}=$ s\&a=Software; 20

U.S. Environmental Protection Agency, 2003, BASINSBetter assessment science integrating point \& nonpoint sources: accessed April 30, 2004, at http://www.epa.gov/ OST/BASINS/.

U.S. Geological Survey, 2001, Elevation program: accessed May 12, 2004, at http://rockyweb.cr.usgs.gov/elevation/.

U.S. Geological Survey, 2003, National land cover characterization: accessed July 20, 2004, at http://landcover.usgs.gov/ natllandcover.asp

Wanielista, M.P., 1990, Hydrology and water quantity control: New York, Wiley, 565 p.

Wicklein, S.M., and Schiffer, D.M., 2002, Simulation of runoff and water quality for 1990 and 2008 land-use conditions in the Reedy Creek watershed, east-central Florida: U.S. Geological Survey Water-Resources Investigations Report 02-4018, 62 p. 
Table 6. Streamflow calibration and testing results, Hydrological Simulation Program—FORTRAN model, Hondo Creek watershed, south-central Texas, 1992-2003.

[acre-ft, acre-feet; $\mathrm{ft}^{3} / \mathrm{s}$, cubic feet per second; --, not applicable]

Hondo Creek near Tarpley (08200000)

\begin{tabular}{|c|c|c|c|c|}
\hline $\begin{array}{l}\text { Comparison of streamflow } \\
\text { volumes and peaks }\end{array}$ & $\begin{array}{l}\text { Measured } \\
\text { streamflow }\end{array}$ & $\begin{array}{l}\text { Simulated } \\
\text { streamflow }\end{array}$ & $\begin{array}{c}\text { Error }^{1} \\
\text { (percent) }\end{array}$ & $\begin{array}{r}\text { Criteria }^{2} \\
\text { (percent) }\end{array}$ \\
\hline \multicolumn{5}{|l|}{ Calibration period 1992-99 } \\
\hline Total flow volume, acre-ft & 282,000 & 282,000 & 0 & 10 \\
\hline Total of highest 10 percent of daily flow volumes, acre- $\mathrm{ft}$ & 192,000 & 183,000 & -4.7 & 15 \\
\hline Total of lowest 50 percent of daily flow volumes, acre-ft & 15,000 & 14,700 & -2.0 & 10 \\
\hline Average of selected storm peaks, $\mathrm{ft}^{3} / \mathrm{s}$ ( 20 storms) & 9,030 & 7,640 & -15.4 & -- \\
\hline \multicolumn{5}{|l|}{ Testing period 2000-2003 } \\
\hline Total flow volume, acre-ft & 186,000 & 191,000 & 2.7 & 10 \\
\hline Total of highest 10 percent of daily flow volumes, acre-ft & 125,000 & 130,000 & 4.0 & 15 \\
\hline Total of lowest 50 percent of daily flow volumes, acre-ft & 7,730 & 8,590 & 11.1 & 10 \\
\hline Average of selected storm peaks, $\mathrm{ft}^{3} / \mathrm{s}$ ( 4 storms) & 20,100 & 16,900 & -15.9 & -- \\
\hline \multicolumn{5}{|l|}{ Entire (calibration and testing) period 1992-2003 } \\
\hline Total flow volume, acre-ft & 468,000 & 473,000 & 1.1 & 10 \\
\hline Total of highest 10 percent of daily flow volumes, acre- $\mathrm{ft}$ & 317,000 & 313,000 & 1.3 & 15 \\
\hline Total of lowest 50 percent of daily flow volumes, acre-ft & 22,700 & 23,300 & 2.6 & 10 \\
\hline Average of selected storm peaks, $\mathrm{ft}^{3} / \mathrm{s}$ ( 24 storms) & 14,000 & 11,900 & -15.0 & -- \\
\hline
\end{tabular}

\begin{tabular}{lcccc}
\hline \multicolumn{1}{c}{ Model-fit statistics 1992-2003 } & Annual & Monthly & Daily mean & Hourly $^{3}$ \\
\hline Number of years, months, days, or hours & 12 & 144 & 4,383 & 104,448 \\
Coefficient of determination & .98 & .92 & .94 & .72 \\
Coefficient of model-fit efficiency & & .92 & .91 & .68 \\
Percentage of time simulated within 10 percent of measured & 41.7 & 18.0 & 18.4 & 18.7 \\
Percentage of time simulated within 25 percent of measured & 58.3 & 36.8 & 33.6 & 33.8 \\
\hline
\end{tabular}




\section{Simulation of Streamflow and Estimation of Recharge to the Edwards Aquifer, South-Central Texas, 1951-2003}

Table 6. Streamflow calibration and testing results, Hydrological Simulation Program—FORTRAN model, Hondo Creek watershed, south-central Texas, 1992-2003-Continued.

Hondo Creek at King Waterhole near Hondo (08200700)

\begin{tabular}{|c|c|c|c|c|}
\hline $\begin{array}{l}\text { Comparison of streamflow } \\
\text { volumes and peaks }\end{array}$ & $\begin{array}{l}\text { Measured } \\
\text { streamflow }\end{array}$ & $\begin{array}{l}\text { Simulated } \\
\text { streamflow }\end{array}$ & $\begin{array}{c}\text { Error }^{1} \\
\text { (percent) }\end{array}$ & $\begin{array}{l}\text { Criteria }^{2} \\
\text { (percent) }\end{array}$ \\
\hline \multicolumn{5}{|l|}{ Calibration period 1992-99 } \\
\hline Total flow volume, acre-ft & 104,000 & 103,000 & 1.0 & 10 \\
\hline Total of highest 10 percent of daily flow volumes, acre-ft & 104,000 & 103,000 & 1.0 & 15 \\
\hline Total of lowest 50 percent of daily flow volumes, acre-ft & 0 & 0 & 0 & 10 \\
\hline Average of selected storm peaks, $\mathrm{ft}^{3} / \mathrm{s}$ (13 storms) & 10,800 & 8,800 & -18.5 & -- \\
\hline \multicolumn{5}{|l|}{ Testing period 2000-2003 } \\
\hline Total flow volume, acre-ft & 81,100 & 84,300 & 3.9 & 10 \\
\hline Total of highest 10 percent of daily flow volumes, acre-ft & 81,100 & 84,300 & 3.9 & 15 \\
\hline Total of lowest 50 percent of daily flow volumes, acre-ft & 0 & 0 & 0 & 10 \\
\hline Average of selected storm peaks, $\mathrm{ft}^{3} / \mathrm{s}$ ( 3 storms) & 19,900 & 33,000 & 65.8 & -- \\
\hline \multicolumn{5}{|l|}{ Entire (calibration and testing) period 1992-2003 } \\
\hline Total flow volume, acre-ft & 185,000 & 187,000 & 1.1 & 10 \\
\hline Total of highest 10 percent of daily flow volumes, acre-ft & 185,000 & 187,000 & .8 & 15 \\
\hline Total of lowest 50 percent of flow volumes, acre-ft & 0 & 0 & 0 & 10 \\
\hline Average of selected storm peaks, $\mathrm{ft}^{3} / \mathrm{s}$ (16 storms) & 12,500 & 13,300 & 6.4 & -- \\
\hline
\end{tabular}

\begin{tabular}{|c|c|c|c|c|}
\hline Model-fit statistics 1992-2003 & Annual & Monthly & Daily mean & Hourly ${ }^{3}$ \\
\hline Number of years, months, days, or hours & 12 & 144 & 4,383 & 105,192 \\
\hline Coefficient of determination & .94 & .94 & .92 & .67 \\
\hline Coefficient of model-fit efficiency ${ }^{4}$ & .93 & .93 & .90 & .66 \\
\hline Percentage of time simulated within 10 percent of measured & 33.3 & 84.7 & 94.2 & 94.6 \\
\hline Percentage of time simulated within 25 percent of measured & 41.7 & 85.4 & 94.7 & 95.0 \\
\hline
\end{tabular}

\footnotetext{
${ }^{1}$ Error $=([$ simulated-measured $] /$ measured $) \times 100$.

${ }^{2}$ Default error criteria from Donigian and others (1984).

${ }^{3}$ Hourly statistics for 0820000 and 08200700 do not include July 2002.

${ }^{4}$ From Nash and Sutcliffe (1970).
} 
Table 7. Streamflow testing and recalibration results, Hydrological Simulation Program—FORTRAN model, San Geronimo Creek watershed, south-central Texas, 1992-93.

[acre-ft, acre-feet; $\mathrm{ft}^{3} / \mathrm{s}$, cubic feet per second; -- not applicable]

Model testing results using process-related parameters from calibrated Hondo Creek HSPF model

\begin{tabular}{|c|c|c|c|c|}
\hline $\begin{array}{l}\text { Comparison of streamflow } \\
\text { volumes and peaks }\end{array}$ & $\begin{array}{l}\text { Measured } \\
\text { streamflow }\end{array}$ & $\begin{array}{l}\text { Simulated } \\
\text { streamflow }\end{array}$ & $\begin{array}{c}\text { Error }^{1} \\
\text { (percent) }\end{array}$ & $\begin{array}{l}\text { Criteria }^{2} \\
\text { (percent) }\end{array}$ \\
\hline \multicolumn{5}{|l|}{ Testing period 1992-93 } \\
\hline Total of highest 10 percent of daily flow volumes, acre-ft & 31,900 & 37,000 & 16.0 & 15 \\
\hline Total of lowest 50 percent of daily flow volumes, acre-ft & 0 & 0 & 0 & 10 \\
\hline Model-fit statistics 1992-93 & Annual & Monthly & Daily & Hourly \\
\hline Number of years, months, days, or hours & 2 & 24 & 731 & 17,544 \\
\hline Coefficient of determination & 1.00 & .87 & .60 & .23 \\
\hline Coefficient of model-fit efficiency ${ }^{3}$ & .84 & .83 & .55 & .23 \\
\hline Percentage of time simulated within 10 percent of measured & 0 & 45.8 & 66.1 & 67.0 \\
\hline Percentage of time simulated within 25 percent of measured & 0 & 58.3 & 69.5 & 70.8 \\
\hline
\end{tabular}

Model results after recalibration with measured San Geronimo Creek streamflow ${ }^{4}$ for $1992-93$

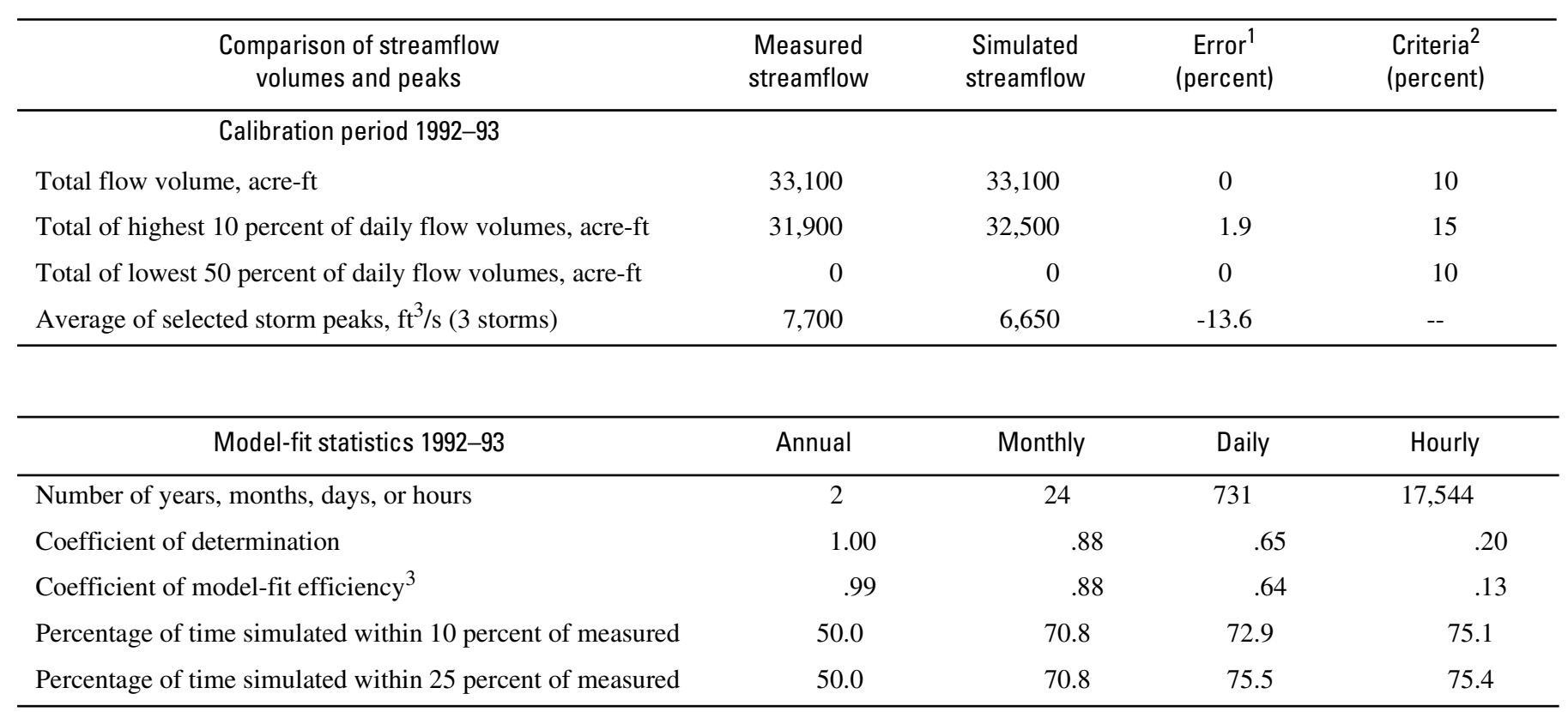

${ }^{1}$ Error $=([$ simulated-measured $] /$ measured $) \times 100$.

${ }^{2}$ Default error criteria from HSPEXP (Lumb and others, 1994).

${ }^{3}$ From Nash and Sutcliffe, 1970.

${ }^{4}$ Measured at San Geronimo Creek Reservoir inflow near Rio Medina (08180590). 


\section{Simulation of Streamflow and Estimation of Recharge to the Edwards Aquifer, South-Central Texas, 1951-2003}

Table 8. Rainfall and simulated evapotranspiration, Hydrological Simulation Program—FORTRAN model, Hondo Creek watershed, south-central Texas, 1992-2003.

[In inches; ET, evapotranspiration]

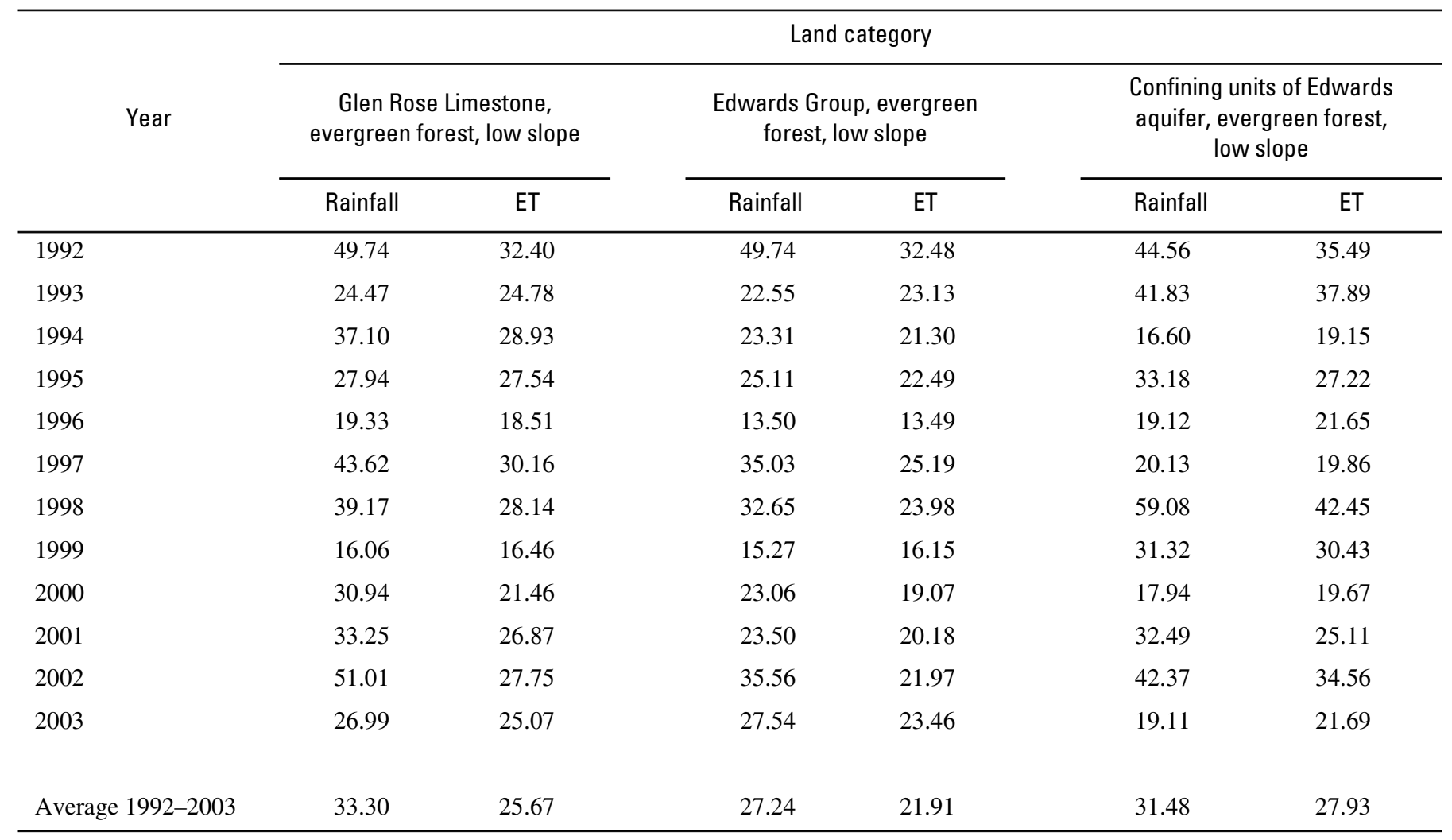


Table 9. Process-related annual parameters for pervious and impervious land segments, Hydrological Simulation Program—FORTRAN models, Hondo Creek and Verde Creek watersheds, south-central Texas.

[Parameter definitions in table 1; PERLND, PERvious LaND; --, not applicable; IMPLND, IMPervious LaND]

Glen Rose Limestone (Trinity aquifer outcrop)

\begin{tabular}{|c|c|c|c|c|c|c|c|c|c|c|c|c|c|c|}
\hline Land cover and slope & AGWETP & AGWRC & BASETP & CEPSC & DEEPFR & INFILT & INTFW & IRC & LSUR & LZSN & NSUR & RETSC & SLSUR & UZSN \\
\hline \multicolumn{15}{|l|}{ PERLND segment } \\
\hline Evergreen forest, low slope & 0 & 0.96 & 0.001 & 0.27 & 0.09 & 0.24 & 0.90 & 0.75 & 400 & 2.3 & 0.30 & -- & 0.04 & 0.22 \\
\hline Deciduous/mixed forest, low slope & 0 & .96 & .001 & .15 & .09 & .24 & .90 & .75 & 400 & 2.3 & .30 & -- & .04 & .22 \\
\hline Shrubland, low slope & 0 & .96 & .001 & .12 & .09 & .24 & .90 & .75 & 400 & 2.3 & .30 & -- & .04 & .22 \\
\hline Grassland, low slope & 0 & .96 & .001 & .10 & .09 & .24 & .90 & .75 & 400 & 2.3 & .30 & -- & .04 & .22 \\
\hline Bare/transitional, low slope & 0 & .96 & .001 & .10 & .09 & .24 & .90 & .75 & 400 & 2.3 & .30 & -- & .04 & .22 \\
\hline Agricultural, low slope & 0 & .96 & .001 & .10 & .09 & .24 & .90 & .75 & 400 & 2.3 & .30 & -- & .04 & .22 \\
\hline Developed, low slope & 0 & .96 & .001 & .10 & .09 & .24 & .90 & .75 & 400 & 2.3 & .30 & -- & .04 & .22 \\
\hline Evergreen forest, medium slope & 0 & .96 & .001 & .26 & .09 & .23 & .90 & .75 & 400 & 2.2 & .30 & -- & .08 & .21 \\
\hline Deciduous/mixed forest, medium slope & 0 & .96 & .001 & .15 & .09 & .23 & .90 & .75 & 400 & 2.2 & .30 & -- & .08 & .21 \\
\hline Shrubland, medium slope & 0 & .96 & .001 & .12 & .09 & .23 & .90 & .75 & 400 & 2.2 & .30 & -- & .08 & .21 \\
\hline Grassland, medium slope & 0 & .96 & .001 & .10 & .09 & .23 & .90 & .75 & 400 & 2.2 & .30 & -- & .08 & .21 \\
\hline Bare/transitional, medium slope & 0 & .96 & .001 & .10 & .09 & .23 & .90 & .75 & 400 & 2.2 & .30 & -- & .08 & .21 \\
\hline Agricultural, medium slope & 0 & .96 & .001 & .10 & .09 & .23 & .90 & .75 & 400 & 2.2 & .30 & -- & .08 & .21 \\
\hline Developed, medium slope & 0 & .96 & .001 & .10 & .09 & .23 & .90 & .75 & 400 & 2.2 & .30 & -- & .08 & .21 \\
\hline Evergreen forest, steep slope & 0 & .96 & .001 & .25 & .09 & .22 & .90 & .75 & 400 & 2.1 & .30 & -- & .14 & .20 \\
\hline Deciduous/mixed forest, steep slope & 0 & .96 & .001 & .15 & .09 & .22 & .90 & .75 & 400 & 2.1 & .30 & -- & .14 & .20 \\
\hline Shrubland, steep slope & 0 & .96 & .001 & .12 & .09 & .22 & .90 & .75 & 400 & 2.1 & .30 & -- & .14 & .20 \\
\hline Grassland, steep slope & 0 & .96 & .001 & .10 & .09 & .22 & .90 & .75 & 400 & 2.1 & .30 & -- & .14 & .20 \\
\hline Bare/transitional, steep slope & 0 & .96 & .001 & .10 & .09 & .22 & .90 & .75 & 400 & 2.1 & .30 & -- & .14 & .20 \\
\hline Agricultural, steep slope & 0 & .96 & .001 & .10 & .09 & .22 & .90 & .75 & 400 & 2.1 & .30 & -- & .14 & .20 \\
\hline Developed, steep slope & 0 & .96 & .001 & .10 & .09 & .22 & .90 & .75 & 400 & 2.1 & .30 & -- & .14 & .20 \\
\hline IMPLND segment & & & & & & & & & & & & & & \\
\hline All impervious & -- & -- & -- & -- & -- & -- & -- & -- & 400 & -- & .10 & .05 & .06 & -- \\
\hline
\end{tabular}


Table 9. Process-related annual parameters for pervious and impervious land segments, Hydrological Simulation Program—FORTRAN models, Hondo Creek and Verde Creek watersheds, south-central Texas-Continued.

Edwards Group outcrop (Edwards aquifer recharge zone)

\begin{tabular}{|c|c|c|c|c|c|c|c|c|c|c|c|c|c|c|}
\hline Land cover and slope & AGWETP & AGWRC & BASETP & CEPSC & DEEPFR & INFILT & INTFW & $\mathrm{IRC}$ & LSUR & LZSN & NSUR & RETSC & SLSUR & UZSN \\
\hline PERLND segment & & & & & & & & & & & & & & \\
\hline Evergreen forest, low slope & 0 & 0.70 & 0 & 0.27 & 0.90 & 0.42 & 0.80 & 0.60 & 400 & 2.2 & 0.30 & -- & 0.04 & 0.30 \\
\hline Deciduous/mixed forest, low slope & 0 & .70 & 0 & .15 & .90 & .42 & .80 & 60 & 400 & 2.2 & .30 & -- & .04 & .30 \\
\hline Shrubland, low slope & 0 & .70 & 0 & .12 & .90 & .42 & .80 & .60 & 400 & 2.2 & .30 & -- & .04 & .30 \\
\hline Grassland, low slope & 0 & .70 & 0 & .10 & .90 & .42 & .80 & .60 & 400 & 2.2 & .30 & -- & .04 & .30 \\
\hline Bare/transitional, low slope & 0 & .70 & 0 & .10 & .90 & .42 & .80 & .60 & 400 & 2.2 & .30 & -- & .04 & .30 \\
\hline Agricultural, low slope & 0 & .70 & 0 & .10 & .90 & .42 & .80 & .60 & 400 & 2.2 & .30 & -- & .04 & .30 \\
\hline Developed, low slope & 0 & .70 & 0 & .10 & .90 & .42 & .80 & .60 & 400 & 2.2 & .30 & -- & .04 & .30 \\
\hline Evergreen forest, medium slope & 0 & .70 & 0 & .26 & .90 & .42 & .80 & 60 & 400 & 2.1 & .30 & -- & .08 & .30 \\
\hline Deciduous/mixed forest, medium slope & 0 & .70 & 0 & .15 & .90 & .42 & .80 & .60 & 400 & 2.1 & .30 & -- & .08 & .30 \\
\hline Shrubland, medium slope & 0 & .70 & 0 & .12 & .90 & .42 & .80 & .60 & 400 & 2.1 & .30 & -- & .08 & .30 \\
\hline Grassland, medium slope & 0 & .70 & 0 & .10 & .90 & .42 & .80 & .60 & 400 & 2.1 & .30 & -- & .08 & .30 \\
\hline Bare/transitional, medium slope & 0 & .70 & 0 & .10 & .90 & .42 & .80 & 60 & 400 & 2.1 & .30 & -- & .08 & .30 \\
\hline Agricultural, medium slope & 0 & .70 & 0 & .10 & .90 & .42 & .80 & .60 & 400 & 2.1 & .30 & -- & .08 & .30 \\
\hline Developed, medium slope & 0 & .70 & 0 & .10 & .90 & .42 & .80 & 60 & 400 & 2.1 & .30 & -- & .08 & .30 \\
\hline Evergreen forest, steep slope & 0 & .70 & 0 & .25 & .90 & .40 & .80 & .60 & 400 & 2.0 & .30 & -- & .14 & .30 \\
\hline Deciduous/mixed forest, steep slope & 0 & .70 & 0 & .15 & .90 & .40 & .80 & .60 & 400 & 2.0 & .30 & -- & .14 & .30 \\
\hline Shrubland, steep slope & 0 & .70 & 0 & .12 & .90 & .40 & .80 & .60 & 400 & 2.0 & .30 & -- & .14 & .30 \\
\hline Grassland, steep slope & 0 & .70 & 0 & .10 & .90 & .40 & .80 & .60 & 400 & 2.0 & .30 & -- & .14 & .30 \\
\hline Bare/transitional, steep slope & 0 & .70 & 0 & .10 & .90 & .40 & .80 & .60 & 400 & 2.0 & .30 & -- & .14 & .30 \\
\hline Agricultural, steep slope & 0 & .70 & 0 & .10 & .90 & .40 & .80 & .60 & 400 & 2.0 & .30 & -- & .14 & .30 \\
\hline Developed, steep slope & 0 & .70 & 0 & .10 & .90 & .40 & .80 & .60 & 400 & 2.0 & .30 & -- & .14 & .30 \\
\hline
\end{tabular}

IMPLND segment

All impervious 
Table 9. Process-related annual parameters for pervious and impervious land segments, Hydrological Simulation Program-FORTRAN models, Hondo Creek and Verde Creek watersheds, south-central Texas-Continued.

Edwards Group remnants (hilltops) overlying Glen Rose Limestone

\begin{tabular}{|c|c|c|c|c|c|c|c|c|c|c|c|c|c|c|}
\hline Land cover and slope & AGWETP & AGWRC & BASETP & CEPSC & DEEPFR & INFILT & INTFW & IRC & LSUR & LZSN & NSUR & RETSC & SLSUR & UZSN \\
\hline \multicolumn{15}{|l|}{ PERLND segment } \\
\hline Evergreen forest, low slope & 0.001 & 0.94 & 0.001 & 0.27 & 0.09 & 0.30 & 0.90 & 0.65 & 400 & 2.3 & 0.30 & -- & 0.04 & 0.22 \\
\hline Deciduous/mixed forest, low slope & .001 & .94 & .001 & .15 & .09 & .30 & .90 & .65 & 400 & 2.3 & .30 & -- & .04 & .22 \\
\hline Shrubland, low slope & .001 & .94 & .001 & .12 & .09 & .30 & .90 & .65 & 400 & 2.3 & .30 & -- & .04 & .22 \\
\hline Grassland, low slope & .001 & .94 & .001 & .10 & .09 & .30 & .90 & .65 & 400 & 2.3 & .30 & -- & .04 & .22 \\
\hline Bare/transitional, low slope & .001 & .94 & .001 & .10 & .09 & .30 & .90 & .65 & 400 & 2.3 & .30 & -- & .04 & .22 \\
\hline Agricultural, low slope & .001 & .94 & .001 & .10 & .09 & .30 & .90 & .65 & 400 & 2.3 & .30 & -- & .04 & .22 \\
\hline Developed, low slope & .001 & .94 & .001 & .10 & .09 & .30 & .90 & .65 & 400 & 2.3 & .30 & -- & .04 & .21 \\
\hline Evergreen forest, medium slope & .001 & .94 & .001 & .26 & .09 & .30 & .90 & .65 & 400 & 2.2 & .30 & -- & .08 & .21 \\
\hline Deciduous/mixed forest, medium slope & .001 & .94 & .001 & .15 & .09 & .30 & .90 & .65 & 400 & 2.2 & .30 & -- & .08 & .21 \\
\hline Shrubland, medium slope & .001 & .94 & .001 & .12 & .09 & .30 & .90 & .65 & 400 & 2.2 & .30 & -- & .08 & .21 \\
\hline Grassland, medium slope & .001 & .94 & .001 & .10 & .09 & .30 & .90 & .65 & 400 & 2.2 & .30 & -- & .08 & .21 \\
\hline Bare/transitional, medium slope & .001 & .94 & .001 & .10 & .09 & .30 & .90 & .65 & 400 & 2.2 & .30 & -- & .08 & .21 \\
\hline Agricultural, medium slope & .001 & .94 & .001 & .10 & .09 & .30 & .90 & .65 & 400 & 2.2 & .30 & -- & .08 & .21 \\
\hline Developed, medium slope & .001 & .94 & .001 & .10 & .09 & .30 & .90 & .65 & 400 & 2.2 & .30 & -- & .08 & .21 \\
\hline Evergreen forest, steep slope & .001 & .94 & .001 & .25 & .09 & .30 & .90 & .65 & 400 & 2.1 & .30 & -- & .14 & .20 \\
\hline Deciduous/mixed forest, steep slope & .001 & .94 & .001 & .15 & .09 & .30 & .90 & .65 & 400 & 2.1 & .30 & -- & .14 & .20 \\
\hline Shrubland, steep slope & .001 & .94 & .001 & .12 & .09 & .30 & .90 & .65 & 400 & 2.1 & .30 & -- & .14 & .20 \\
\hline Grassland, steep slope & .001 & .94 & .001 & .10 & .09 & .30 & .90 & .65 & 400 & 2.1 & .30 & -- & .14 & .20 \\
\hline Bare/transitional, steep slope & .001 & .94 & .001 & .10 & .09 & .30 & .90 & .65 & 400 & 2.1 & .30 & -- & .14 & .20 \\
\hline Agricultural, steep slope & .001 & .94 & .001 & .10 & .09 & .30 & .90 & .65 & 400 & 2.1 & .30 & -- & .14 & .20 \\
\hline Developed, steep slope & .001 & .94 & .001 & .10 & .09 & .30 & .90 & .65 & 400 & 2.1 & .30 & -- & .14 & .20 \\
\hline \multicolumn{15}{|l|}{ IMPLND segment } \\
\hline All impervious & -- & -- & -- & -- & -- & -- & -- & -- & 400 & -- & .10 & 0.05 & .04 & -- \\
\hline
\end{tabular}


Table 9. Process-related annual parameters for pervious and impervious land segments, Hydrological Simulation Program—FORTRAN models, Hondo Creek and Verde Creek watersheds, south-central Texas-Continued.

Edwards aquifer confining units

\begin{tabular}{|c|c|c|c|c|c|c|c|c|c|c|c|c|c|c|}
\hline Land cover and slope & AGWE & TP AGWRC & C BASETP & CEPSC & DEEPFR & INFILT & INTFW & IRC & LSUR & LZSN & NSUR & RETSC & SLSUR & UZSN \\
\hline \multicolumn{15}{|l|}{ PERLND segment } \\
\hline Evergreen forest, low slope & 0.001 & 0.75 & 0.001 & 0.27 & 0.20 & 0.35 & 0.40 & 0.70 & 400 & 5.0 & 0.30 & -- & 0.04 & 0.50 \\
\hline Deciduous/mixed forest, low slope & .001 & .75 & .001 & .15 & .20 & .35 & .40 & .70 & 400 & 5.0 & .30 & -- & .04 & .50 \\
\hline Shrubland, low slope & .001 & .75 & .001 & .12 & .20 & .35 & .40 & .70 & 400 & 5.0 & .30 & -- & .04 & .50 \\
\hline Grassland, low slope & .001 & .75 & .001 & .10 & .20 & .35 & .40 & .70 & 400 & 5.0 & .30 & -- & .04 & .50 \\
\hline Bare/transitional, low slope & .001 & .75 & .001 & .10 & .20 & .35 & .40 & .70 & 400 & 5.0 & .30 & -- & .04 & .50 \\
\hline Agricultural, low slope & .001 & .75 & .001 & .10 & .20 & .35 & .40 & .70 & 400 & 5.0 & .30 & -- & .04 & .50 \\
\hline Developed, low slope & .001 & .75 & .001 & .10 & .20 & .35 & .40 & .70 & 400 & 5.0 & .30 & -- & .04 & .50 \\
\hline Evergreen forest, medium slope & .001 & .75 & .001 & .26 & .20 & .35 & .40 & .70 & 400 & 5.0 & .30 & -- & .08 & .50 \\
\hline Deciduous/mixed forest, medium slo & .001 & .75 & .001 & .15 & .20 & .35 & .40 & .70 & 400 & 5.0 & .30 & -- & .08 & .50 \\
\hline Shrubland, medium slope & .001 & .75 & .001 & .12 & .20 & .35 & .40 & .70 & 400 & 5.0 & .30 & -- & .08 & .50 \\
\hline Grassland, medium slope & .001 & .75 & .001 & .10 & .20 & .35 & .40 & .70 & 400 & 5.0 & .30 & -- & .08 & .50 \\
\hline Bare/transitional, medium slope & .001 & .75 & .001 & .10 & .20 & .35 & .40 & .70 & 400 & 5.0 & .30 & -- & .08 & .50 \\
\hline Agricultural, medium slope & .001 & .75 & .001 & .10 & .20 & .35 & .40 & .70 & 400 & 5.0 & .30 & -- & .08 & .50 \\
\hline Developed, medium slope & .001 & .75 & .001 & .10 & .20 & .35 & .40 & .70 & 400 & 5.0 & .30 & -- & .08 & .50 \\
\hline \multicolumn{15}{|l|}{ IMPLND segment } \\
\hline All impervious & -- & -- & -- & -- & -- & -- & -- & -- & 400 & -- & .10 & 0.05 & .04 & -- \\
\hline \multicolumn{15}{|l|}{ Alluvial deposits } \\
\hline Land cover and slope & AGWETP & AGWRC & BASETP & CEPSC & DEEPFR & INFILT & INTFW & IRC & LSUR & LZSN & NSUR & RETSC & SLSUR & UZSN \\
\hline \multicolumn{15}{|l|}{ PERLND segment } \\
\hline Evergreen forest, low slope & 0.001 & 0.85 & 0.001 & 0.27 & 0.45 & 0.35 & 1.50 & 0.70 & 400 & 3.0 & 0.30 & -- & 0.04 & 0.60 \\
\hline Deciduous/mixed forest, low slope & .001 & .85 & .001 & .15 & .45 & .35 & 1.50 & .70 & 400 & 3.0 & .30 & -- & .04 & .60 \\
\hline Shrubland, low slope & .001 & .85 & .001 & .12 & .45 & .35 & 1.50 & .70 & 400 & 3.0 & .30 & -- & .04 & .60 \\
\hline Grassland, low slope & .001 & .85 & .001 & .10 & .45 & .35 & 1.50 & .70 & 400 & 3.0 & .30 & -- & .04 & .60 \\
\hline Bare/transitional, low slope & .001 & .85 & .001 & .10 & .45 & .35 & 1.50 & .70 & 400 & 3.0 & .30 & -- & .04 & .60 \\
\hline Agricultural, low slope & .001 & .85 & .001 & .10 & .45 & .35 & 1.50 & .70 & 400 & 3.0 & .30 & -- & .04 & .60 \\
\hline Developed, low slope & .001 & .85 & .001 & .10 & .45 & .35 & 1.50 & .70 & 400 & 3.0 & .30 & -- & .04 & .60 \\
\hline \multicolumn{15}{|l|}{ IMPLND segment } \\
\hline All impervious & -- & -- & -- & -- & -- & -- & -- & -- & 400 & -- & .10 & 0.05 & .04 & -- \\
\hline
\end{tabular}


Table 10. Process-related annual parameters for pervious and impervious land segments, Hydrological Simulation Program—FORTRAN model, San Geronimo Creek watershed, south-central Texas.

[Parameter definitions in table 1; PERLND, PERvious LaND; --, not applicable; IMPLND, IMPervious LaND]

Glen Rose Limestone (Trinity aquifer outcrop)

\begin{tabular}{|c|c|c|c|c|c|c|c|c|c|c|c|c|c|c|}
\hline Land cover and slope & AGWETP & AGWRC & BASETP & CEPSC & DEEPFR & INFILT & INTFW & $\mathrm{IRC}$ & LSUR & LZSN & NSUR & RETSC & SLSUR & UZSN \\
\hline \multicolumn{15}{|l|}{ PERLND segment } \\
\hline Evergreen forest, low slope & 0.001 & 0.95 & 0.001 & 0.27 & 0.22 & 0.3 & 1.0 & 0.8 & 400 & 3.6 & 0.3 & -- & 0.04 & 0.24 \\
\hline Deciduous/mixed forest, low slope & .001 & .95 & .001 & .15 & .22 & .3 & 1.0 & .8 & 400 & 3.6 & .3 & -- & .04 & .24 \\
\hline Shrubland, low slope & .001 & .95 & .001 & .12 & .22 & .3 & 1.0 & .8 & 400 & 3.6 & .3 & -- & .04 & .24 \\
\hline Grassland, low slope & .001 & .95 & .001 & .10 & .22 & .3 & 1.0 & .8 & 400 & 3.6 & .3 & -- & .04 & .24 \\
\hline Bare/transitional, low slope & .001 & .95 & .001 & .10 & .22 & .3 & 1.0 & .8 & 400 & 3.6 & .3 & -- & .04 & .24 \\
\hline Agricultural, low slope & .001 & .95 & .001 & .10 & .22 & .3 & 1.0 & .8 & 400 & 3.6 & .3 & -- & .04 & .24 \\
\hline Developed, low slope & .001 & .95 & .001 & .10 & .22 & .3 & 1.0 & .8 & 400 & 3.6 & .3 & -- & .04 & .24 \\
\hline Evergreen forest, medium slope & .001 & .95 & .001 & .26 & .22 & .3 & 1.0 & .8 & 400 & 3.6 & .3 & -- & .08 & .24 \\
\hline Deciduous/mixed forest, medium slope & .001 & .95 & .001 & .15 & .22 & .3 & 1.0 & .8 & 400 & 3.6 & .3 & -- & .08 & .24 \\
\hline Shrubland, medium slope & .001 & .95 & .001 & .12 & .22 & .3 & 1.0 & .8 & 400 & 3.6 & .3 & -- & .08 & .24 \\
\hline Grassland, medium slope & .001 & .95 & .001 & .10 & .22 & .3 & 1.0 & .8 & 400 & 3.6 & .3 & -- & .08 & .24 \\
\hline Bare/transitional, medium slope & .001 & .95 & .001 & .10 & .22 & .3 & 1.0 & .8 & 400 & 3.6 & .3 & -- & .08 & .24 \\
\hline Agricultural, medium slope & .001 & .95 & .001 & .10 & .22 & .3 & 1.0 & .8 & 400 & 3.6 & .3 & -- & .08 & .24 \\
\hline Developed, medium slope & .001 & .95 & .001 & .10 & .22 & .3 & 1.0 & .8 & 400 & 3.6 & .3 & -- & .08 & .24 \\
\hline Evergreen forest, steep slope & .001 & .95 & .001 & .25 & .22 & .3 & 1.0 & .8 & 400 & 3.6 & .3 & -- & .14 & .22 \\
\hline Deciduous/mixed forest, steep slope & .001 & .95 & .001 & .15 & .22 & .3 & 1.0 & .8 & 400 & 3.6 & .3 & -- & .14 & .22 \\
\hline Shrubland, steep slope & .001 & .95 & .001 & .12 & .22 & .3 & 1.0 & .8 & 400 & 3.6 & .3 & -- & .14 & .22 \\
\hline Grassland, steep slope & .001 & .95 & .001 & .10 & .22 & .3 & 1.0 & .8 & 400 & 3.6 & .3 & -- & .14 & .22 \\
\hline Bare/transitional, steep slope & .001 & .95 & .001 & .10 & .22 & .3 & 1.0 & .8 & 400 & 3.6 & .3 & -- & .14 & .22 \\
\hline Agricultural, steep slope & .001 & .95 & .001 & .10 & .22 & .3 & 1.0 & .8 & 400 & 3.6 & .3 & -- & .14 & .22 \\
\hline Developed, steep slope & .001 & .95 & .001 & .10 & .22 & .3 & 1.0 & .8 & 400 & 3.6 & .3 & -- & .14 & .22 \\
\hline \multicolumn{15}{|l|}{ IMPLND segment } \\
\hline All impervious & -- & -- & -- & -- & -- & -- & -- & -- & 400 & -- & .10 & 0.05 & .06 & -- \\
\hline
\end{tabular}


Table 10. Process-related annual parameters for pervious and impervious land segments, Hydrological Simulation Program-FORTRAN model, San Geronimo Creek watershed, south-central Texas-Continued.

Edwards Group outcrop (Edwards aquifer recharge zone)

\begin{tabular}{|c|c|c|c|c|c|c|c|c|c|c|c|c|c|c|}
\hline Land cover and slope & AGWETP & AGWRC & BASETP & CEPSC & DEEPFR & INFILT & INTFW & IRC & LSUR & LZSN & NSUR & RETSC & SLSUR & UZSN \\
\hline PERLND segment & & & & & & & & & & & & & & \\
\hline Evergreen forest, low slope & 0 & 0.75 & 0 & 0.27 & 0.9 & 0.4 & 0.8 & 0.6 & 500 & 2.8 & 0.3 & -- & 0.04 & 0.4 \\
\hline Deciduous/mixed forest, low slope & 0 & .75 & 0 & .15 & .9 & .4 & .8 & 6 & 500 & 2.8 & .3 & -- & .04 & .4 \\
\hline Shrubland, low slope & 0 & .75 & 0 & .12 & .9 & .4 & .8 & 6 & 500 & 2.8 & .3 & -- & .04 & .4 \\
\hline Grassland, low slope & 0 & .75 & 0 & .10 & .9 & .4 & .8 & 6 & 500 & 2.8 & .3 & -- & .04 & .4 \\
\hline Bare/transitional, low slope & 0 & .75 & 0 & .10 & .9 & .4 & .8 & 6 & 500 & 2.8 & .3 & -- & .04 & .4 \\
\hline Agricultural, low slope & 0 & .75 & 0 & .10 & .9 & .4 & .8 & .6 & 500 & 2.8 & .3 & -- & .04 & .4 \\
\hline Developed, low slope & 0 & .75 & 0 & .10 & .9 & .4 & .8 & 6 & 500 & 2.8 & .3 & -- & .04 & .4 \\
\hline Evergreen forest, medium slope & 0 & .75 & 0 & .26 & .9 & .4 & .8 & 6 & 500 & 2.8 & .3 & -- & .08 & .4 \\
\hline Deciduous/mixed forest, medium slope & 0 & .75 & 0 & .15 & .9 & .4 & .8 & 6 & 500 & 2.8 & .3 & -- & .08 & .4 \\
\hline Shrubland, medium slope & 0 & .75 & 0 & .12 & .9 & .4 & .8 & .6 & 500 & 2.8 & .3 & -- & .08 & .4 \\
\hline Grassland, medium slope & 0 & .75 & 0 & .10 & .9 & .4 & .8 & 6 & 500 & 2.8 & .3 & -- & .08 & .4 \\
\hline Bare/transitional, medium slope & 0 & .75 & 0 & .10 & .9 & .4 & .8 & 6 & 500 & 2.8 & .3 & -- & .08 & .4 \\
\hline Agricultural, medium slope & 0 & .75 & 0 & .10 & .9 & .4 & .8 & 6 & 500 & 2.8 & .3 & -- & .08 & .4 \\
\hline Developed, medium slope & 0 & .75 & 0 & .10 & .9 & .4 & .8 & 6 & 500 & 2.8 & .3 & -- & .08 & .4 \\
\hline Evergreen forest, steep slope & 0 & .75 & 0 & .25 & .9 & .4 & .8 & .6 & 500 & 2.8 & .3 & -- & .13 & .4 \\
\hline Deciduous/mixed forest, steep slope & 0 & .75 & 0 & .15 & .9 & .4 & .8 & 6 & 500 & 2.8 & .3 & -- & .13 & .4 \\
\hline Shrubland, steep slope & 0 & .75 & 0 & .12 & .9 & .4 & .8 & .6 & 500 & 2.8 & .3 & -- & .13 & .4 \\
\hline Grassland, steep slope & 0 & .75 & 0 & .10 & .9 & .4 & .8 & 6 & 500 & 2.8 & .3 & -- & .13 & .4 \\
\hline Bare/transitional, steep slope & 0 & .75 & 0 & .10 & .9 & .4 & .8 & .6 & 500 & 2.8 & .3 & -- & .13 & .4 \\
\hline Agricultural, steep slope & 0 & .75 & 0 & .10 & .9 & .4 & .8 & .6 & 500 & 2.8 & .3 & -- & .13 & .4 \\
\hline Developed, steep slope & 0 & .75 & 0 & .10 & .9 & .4 & .8 & 6 & 500 & 2.8 & .3 & -- & .13 & .4 \\
\hline
\end{tabular}

\section{IMPLND segment}

All impervious 
Table 10. Process-related annual parameters for pervious and impervious land segments, Hydrological Simulation Program—FORTRAN model, San Geronimo Creek watershed, south-central Texas-Continued.

Edwards Group remnants (hilltops) overlying Glen Rose Limestone

\begin{tabular}{|c|c|c|c|c|c|c|c|c|c|c|c|c|c|c|}
\hline Land cover and slope & AGWETP & AGWRC & BASETP & CEPSC & DEEPFR & INFILT & INTFW & IRC & LSUR & LZSN & NSUR & RETSC & SLSUR & UZSN \\
\hline \multicolumn{15}{|l|}{ PERLND segment } \\
\hline Evergreen forest, low slope & 0.001 & 0.94 & 0.001 & 0.27 & 0.2 & 0.35 & 0.9 & 0.7 & 400 & 3.6 & 0.3 & -- & 0.04 & 0.4 \\
\hline Deciduous/mixed forest, low slope & .001 & .94 & .001 & .15 & .2 & .35 & .9 & .7 & 400 & 3.6 & .3 & -- & .04 & .4 \\
\hline Shrubland, low slope & .001 & .94 & .001 & .12 & .2 & .35 & .9 & .7 & 400 & 3.6 & .3 & -- & .04 & .4 \\
\hline Grassland, low slope & .001 & .94 & .001 & .10 & .2 & .35 & .9 & .7 & 400 & 3.6 & .3 & -- & .04 & .4 \\
\hline Bare/transitional, low slope & .001 & .94 & .001 & .10 & .2 & .35 & .9 & .7 & 400 & 3.6 & .3 & -- & .04 & .4 \\
\hline Agricultural, low slope & .001 & .94 & .001 & .10 & .2 & .35 & .9 & .7 & 400 & 3.6 & .3 & -- & .04 & .4 \\
\hline Developed, low slope & .001 & .94 & .001 & .10 & .2 & .35 & .9 & .7 & 400 & 3.6 & .3 & -- & .04 & .4 \\
\hline Evergreen forest, medium slope & .001 & .94 & .001 & .26 & .2 & .35 & .9 & .7 & 400 & 3.6 & .3 & -- & .08 & .4 \\
\hline Deciduous/mixed forest, medium slope & .001 & .94 & .001 & .15 & .2 & .35 & .9 & .7 & 400 & 3.6 & .3 & -- & .08 & .4 \\
\hline Shrubland, medium slope & .001 & .94 & .001 & .12 & .2 & .35 & .9 & .7 & 400 & 3.6 & .3 & -- & .08 & .4 \\
\hline Grassland, medium slope & .001 & .94 & .001 & .10 & .2 & .35 & .9 & .7 & 400 & 3.6 & .3 & -- & .08 & .4 \\
\hline Bare/transitional, medium slope & .001 & .94 & .001 & .10 & .2 & .35 & .9 & .7 & 400 & 3.6 & .3 & -- & .08 & .4 \\
\hline Agricultural, medium slope & .001 & .94 & .001 & .10 & .2 & .35 & .9 & .7 & 400 & 3.6 & .3 & -- & .08 & .4 \\
\hline Developed, medium slope & .001 & .94 & .001 & .10 & .2 & .35 & .9 & .7 & 400 & 3.6 & .3 & -- & .08 & .4 \\
\hline Evergreen forest, steep slope & .001 & .94 & .001 & .25 & .2 & .35 & .9 & .7 & 400 & 3.6 & .3 & -- & .14 & .4 \\
\hline Deciduous/mixed forest, steep slope & .001 & .94 & .001 & .15 & .2 & .35 & .9 & .7 & 400 & 3.6 & .3 & -- & .14 & .4 \\
\hline Shrubland, steep slope & .001 & .94 & .001 & .12 & .2 & .35 & .9 & .7 & 400 & 3.6 & .3 & -- & .14 & .4 \\
\hline Grassland, steep slope & .001 & .94 & .001 & .10 & .2 & .35 & .9 & .7 & 400 & 3.6 & .3 & -- & .14 & .4 \\
\hline Bare/transitional, steep slope & .001 & .94 & .001 & .10 & .2 & .35 & .9 & .7 & 400 & 3.6 & .3 & -- & .14 & .4 \\
\hline Agricultural, steep slope & .001 & .94 & .001 & .10 & .2 & .35 & .9 & .7 & 400 & 3.6 & .3 & -- & .14 & .4 \\
\hline Developed, steep slope & .001 & .94 & .001 & .10 & .2 & .35 & .9 & .7 & 400 & 3.6 & .3 & -- & .14 & .4 \\
\hline \multicolumn{15}{|l|}{ IMPLND segment } \\
\hline All impervious & -- & -- & -- & -- & -- & -- & -- & -- & 400 & -- & .10 & 0.05 & .04 & -- \\
\hline
\end{tabular}


Table 10. Process-related annual parameters for pervious and impervious land segments, Hydrological Simulation Program—FORTRAN model, San Geronimo Creek watershed, south-central Texas-Continued.

Edwards aquifer confining units

\begin{tabular}{|c|c|c|c|c|c|c|c|c|c|c|c|c|c|c|}
\hline Land cover and slope & AGWET & AGWRC & BASETP & CEPSC & DEEPFR & INFILT & INTFW & IRC & LSUR & LZSN & NSUR & RETSC & SLSUR & UZSN \\
\hline \multicolumn{15}{|l|}{ PERLND segment } \\
\hline Evergreen forest, low slope & 0.001 & 0.75 & 0.001 & 0.27 & 0.2 & 0.35 & 0.4 & 0.7 & 400 & 5.0 & 0.3 & -- & 0.04 & 0.5 \\
\hline Deciduous/mixed forest, low slope & .001 & .75 & .001 & .15 & .2 & .35 & .4 & .7 & 400 & 5.0 & .3 & -- & .04 & .5 \\
\hline Shrubland, low slope & .001 & .75 & .001 & .12 & .2 & .35 & .4 & .7 & 400 & 5.0 & .3 & -- & .04 & .5 \\
\hline Grassland, low slope & .001 & .75 & .001 & .10 & .2 & .35 & .4 & .7 & 400 & 5.0 & .3 & -- & .04 & .5 \\
\hline Bare/transitional, low slope & .001 & .75 & .001 & .10 & .2 & .35 & .4 & .7 & 400 & 5.0 & .3 & -- & .04 & .5 \\
\hline Agricultural, low slope & .001 & .75 & .001 & .10 & .2 & .35 & .4 & .7 & 400 & 5.0 & .3 & -- & .04 & .5 \\
\hline Developed, low slope & .001 & .75 & .001 & .10 & .2 & .35 & .4 & .7 & 400 & 5.0 & .3 & -- & .04 & .5 \\
\hline Evergreen forest, medium slope & .001 & .75 & .001 & .26 & .2 & .35 & .4 & .7 & 400 & 5.0 & .3 & -- & .08 & .5 \\
\hline Deciduous/mixed forest, medium slop & .001 & .75 & .001 & .15 & .2 & .35 & .4 & .7 & 400 & 5.0 & .3 & -- & .08 & .5 \\
\hline Shrubland, medium slope & .001 & .75 & .001 & .12 & .2 & .35 & .4 & .7 & 400 & 5.0 & .3 & -- & .08 & .5 \\
\hline Grassland, medium slope & .001 & .75 & .001 & .10 & .2 & .35 & .4 & .7 & 400 & 5.0 & .3 & -- & .08 & .5 \\
\hline Bare/transitional, medium slope & .001 & .75 & .001 & .10 & .2 & .35 & .4 & .7 & 400 & 5.0 & .3 & -- & .08 & .5 \\
\hline Agricultural, medium slope & .001 & .75 & .001 & .10 & .2 & .35 & .4 & .7 & 400 & 5.0 & .3 & -- & .08 & .5 \\
\hline Developed, medium slope & .001 & .75 & .001 & .10 & .2 & .35 & .4 & .7 & 400 & 5.0 & .3 & -- & .08 & .5 \\
\hline \multicolumn{15}{|l|}{ IMPLND } \\
\hline All impervious & -- & -- & -- & -- & -- & -- & -- & -- & 400 & -- & .10 & 0.05 & .04 & -- \\
\hline \multicolumn{15}{|l|}{ Alluvial deposits } \\
\hline Land cover and slope & AGWETP & AGWRC & BASETP & CEPSC & DEEPFR & INFILT & INTFW & IRC & LSUR & LZSN & NSUR & RETSC & SLSUR & UZSN \\
\hline \multicolumn{15}{|l|}{ PERLND segment } \\
\hline Evergreen forest, low slope & 0.001 & 0.85 & 0.001 & 0.27 & 0.45 & 0.35 & 1.5 & 0.7 & 400 & 3.5 & 0.3 & -- & 0.04 & 0.6 \\
\hline Deciduous/mixed forest, low slope & .001 & .85 & .001 & .15 & .45 & .35 & 1.5 & .7 & 400 & 3.5 & .3 & -- & .04 & 6 \\
\hline Shrubland, low slope & .001 & .85 & .001 & .12 & .45 & .35 & 1.5 & .7 & 400 & 3.5 & .3 & -- & .04 & .6 \\
\hline Grassland, low slope & .001 & .85 & .001 & .10 & .45 & .35 & 1.5 & .7 & 400 & 3.5 & .3 & -- & .04 & 6 \\
\hline Bare/transitional, low slope & .001 & .85 & .001 & .10 & .45 & .35 & 1.5 & .7 & 400 & 3.5 & .3 & -- & .04 & 6 \\
\hline Agricultural, low slope & .001 & .85 & .001 & .10 & .45 & .35 & 1.5 & .7 & 400 & 3.5 & .3 & -- & .04 & .6 \\
\hline Developed, low slope & .001 & .85 & .001 & .10 & .45 & .35 & 1.5 & .7 & 400 & 3.5 & .3 & -- & .04 & 6 \\
\hline \multicolumn{15}{|l|}{ IMPLND } \\
\hline All impervious & -- & -- & -- & -- & -- & -- & -- & -- & 400 & -- & .10 & 0.05 & .04 & -- \\
\hline
\end{tabular}


Table 11. Monthly values of lower-zone evapotranspiration (LZETP) parameter, Hydrological Simulation Program—FORTRAN models, Hondo Creek, Verde Creek, and San Geronimo Creek watersheds, south-central Texas.

[PERLND, PERvious LaND]

All geology-slope combinations

\begin{tabular}{lrrrrrrrrrrrr}
\hline \multicolumn{1}{c}{ Land cover } & Jan. & Feb. & Mar. & Apr. & May & June & July & Aug. & Sept. & Oct. & Nov. & Dec. \\
\hline \multicolumn{1}{c}{ PERLND segment } & & & & & & & & & & & & \\
Evergreen forest & 0.4 & 0.4 & 0.5 & 0.6 & 0.6 & 0.6 & 0.6 & 0.6 & 0.6 & 0.5 & 0.4 & 0.4 \\
Deciduous/mixed forest & .2 & .2 & .4 & .6 & .7 & .7 & .7 & .7 & .6 & .5 & .4 & .3 \\
Shrubland & .2 & .2 & .4 & .6 & .7 & .7 & .7 & .7 & .6 & .5 & .4 & .3 \\
Grassland & .2 & .2 & .4 & .6 & .7 & .7 & .7 & .7 & .6 & .5 & .4 & .3 \\
Bare/transitional & .2 & .2 & .4 & .6 & .7 & .7 & .7 & .7 & .6 & .5 & .4 & .3 \\
Agriculture & .2 & .2 & .4 & .5 & .5 & .5 & .5 & .5 & .4 & .3 & .2 & .2 \\
Developed & .2 & .2 & .4 & .6 & .7 & .7 & .7 & .7 & .6 & .6 & .5 & .3 \\
\hline
\end{tabular}

Table 12. Simulated average annual streamflow volumes for Hondo Creek, Verde Creek, and San Geronimo Creek watersheds, southcentral Texas, 1951-2003.

[Total streamflow for a watershed includes all surface runoff, interflow, and base flow that originates in the watershed and reaches the stream channel. Streamflow at watershed outlet is difference between total streamflow and streamflow lost to channel infiltration.]

\begin{tabular}{lccc}
\hline & $\begin{array}{c}\text { Hondo } \\
\text { Creek }\end{array}$ & $\begin{array}{c}\text { Verde } \\
\text { Creek }\end{array}$ & $\begin{array}{c}\text { San Geronimo } \\
\text { Creek }\end{array}$ \\
\hline Watershed area, acres & 102,702 & 140,088 & 43,889 \\
$\begin{array}{l}\text { Approximate area of Edwards aquifer recharge zone and contributing } \\
\text { drainage area upstream from the recharge zone, acres }\end{array}$ & 90,200 & 92,800 & 36,120 \\
Average annual rainfall, inches & 30.40 & 29.72 & 32.09 \\
Average annual total streamflow, acre-feet & 45,400 & 32,400 & 11,100 \\
Average annual total streamflow, inches & 5.30 & 2.78 & 3.03 \\
Average annual streamflow at watershed outlet, acre-feet & 13,000 & 16,200 & 6,920 \\
Average annual streamflow at watershed outlet, inches & 1.52 & 1.39 & 1.89 \\
\hline
\end{tabular}


Table 13. Estimated annual rainfall and Edwards aquifer recharge, Hondo Creek, Verde Creek, and San Geronimo Creek watersheds, south-central Texas, 1951-2003.

\begin{tabular}{|c|c|c|c|c|c|c|}
\hline \multirow{2}{*}{$\begin{array}{c}\text { Calendar } \\
\text { year }\end{array}$} & \multicolumn{2}{|c|}{ Hondo Creek } & \multicolumn{2}{|c|}{ Verde Creek } & \multicolumn{2}{|c|}{ San Geronimo Creek $^{1}$} \\
\hline & $\begin{array}{l}\text { Rainfall } \\
\text { (inches) }\end{array}$ & $\begin{array}{c}\text { Recharge } \\
\text { (acre-feet) }\end{array}$ & $\begin{array}{l}\text { Rainfall } \\
\text { (inches) }\end{array}$ & $\begin{array}{c}\text { Recharge } \\
\text { (acre-feet) }\end{array}$ & $\begin{array}{r}\text { Rainfall } \\
\text { (inches) }\end{array}$ & $\begin{array}{r}\text { Recharge } \\
\text { (acre-feet) }\end{array}$ \\
\hline 1951 & 18.69 & 9,760 & 20.72 & 8,750 & 19.81 & 230 \\
\hline 1952 & 25.17 & 14,200 & 26.56 & 10,500 & 34.11 & 3,930 \\
\hline 1953 & 19.27 & 21,800 & 18.97 & 14,400 & 19.99 & 1,580 \\
\hline 1954 & 14.59 & 5,840 & 13.60 & 3,960 & 11.44 & 100 \\
\hline 1955 & 19.44 & 4,170 & 18.58 & 4,090 & 17.83 & 210 \\
\hline 1956 & 10.95 & 1,920 & 11.90 & 1,760 & 12.14 & 150 \\
\hline 1957 & 38.65 & 58,500 & 38.16 & 38,800 & 46.61 & 11,400 \\
\hline 1958 & 43.17 & 73,200 & 42.55 & 48,500 & 41.44 & 9,750 \\
\hline 1959 & 29.36 & 21,500 & 32.91 & 14,500 & 37.30 & 4,190 \\
\hline 1960 & 34.87 & 36,700 & 33.86 & 24,800 & 32.76 & 2,870 \\
\hline 1961 & 28.29 & 40,600 & 26.79 & 26,800 & 24.92 & 2,810 \\
\hline 1962 & 20.57 & 6,360 & 21.61 & 4,850 & 25.16 & 1,600 \\
\hline 1963 & 20.47 & 9,450 & 19.19 & 6,840 & 19.24 & 700 \\
\hline 1964 & 21.90 & 20,800 & 24.66 & 14,200 & 27.23 & 2,780 \\
\hline 1965 & 30.51 & 30,100 & 31.92 & 22,000 & 39.03 & 7,720 \\
\hline 1966 & 19.37 & 9,040 & 25.11 & 9,170 & 30.20 & 5,230 \\
\hline 1967 & 28.32 & 41,900 & 28.56 & 27,800 & 27.39 & 3,980 \\
\hline 1968 & 45.45 & 85,800 & 35.21 & 53,800 & 29.02 & 4,420 \\
\hline 1969 & 36.81 & 52,500 & 36.63 & 35,300 & 38.26 & 6,830 \\
\hline 1970 & 27.02 & 33,300 & 23.60 & 22,500 & 22.11 & 2,910 \\
\hline 1971 & 43.08 & 71,300 & 37.58 & 43,900 & 38.46 & 8,460 \\
\hline 1972 & 36.44 & 55,900 & 32.66 & 33,700 & 33.05 & 3,530 \\
\hline 1973 & 41.43 & 46,900 & 45.65 & 33,300 & 50.96 & 12,800 \\
\hline 1974 & 40.85 & 57,600 & 37.69 & 38,800 & 37.08 & 5,260 \\
\hline 1975 & 32.34 & 40,500 & 30.09 & 28,700 & 30.13 & 5,130 \\
\hline 1976 & 40.60 & 68,700 & 42.30 & 48,200 & 44.46 & 10,600 \\
\hline 1977 & 28.96 & 40,500 & 25.37 & 26,800 & 28.26 & 3,530 \\
\hline 1978 & 34.08 & 37,500 & 32.71 & 25,100 & 35.09 & 5,990 \\
\hline 1979 & 28.46 & 39,900 & 28.28 & 28,200 & 34.49 & 8,720 \\
\hline 1980 & 30.00 & 34,900 & 26.20 & 24,100 & 26.33 & 1,890 \\
\hline 1981 & 41.49 & 69,000 & 37.14 & 44,700 & 38.56 & 10,600 \\
\hline 1982 & 22.68 & 15,400 & 22.77 & 11,700 & 25.82 & 2,380 \\
\hline 1983 & 32.13 & 40,000 & 28.94 & 26,800 & 31.00 & 2,230 \\
\hline 1984 & 28.84 & 20,500 & 24.64 & 16,200 & 22.47 & 1,660 \\
\hline 1985 & 36.77 & 65,800 & 35.70 & 44,200 & 39.24 & 9,720 \\
\hline 1986 & 30.84 & 36,300 & 34.26 & 28,800 & 40.16 & 12,800 \\
\hline 1987 & 46.42 & 68,600 & 43.17 & 44,600 & 39.82 & 11,300 \\
\hline 1988 & 20.64 & 22,500 & 17.00 & 13,800 & 16.56 & 180 \\
\hline 1989 & 21.14 & 21,000 & 19.50 & 13,700 & 22.33 & 700 \\
\hline 1990 & 28.01 & 36,700 & 25.73 & 24,900 & 34.19 & 7,750 \\
\hline 1991 & 44.08 & 60,000 & 41.95 & 40,900 & 47.36 & 7,260 \\
\hline 1992 & 48.98 & 117,000 & 46.67 & 73,800 & 55.65 & 26,700 \\
\hline 1993 & 26.29 & 17,100 & 26.87 & 16,000 & 22.13 & 2,500 \\
\hline 1994 & 28.95 & 26,000 & 28.57 & 20,400 & 37.54 & 6,640 \\
\hline 1995 & 27.65 & 23,300 & 27.99 & 17,900 & 28.31 & 2,160 \\
\hline 1996 & 17.12 & 3,800 & 18.17 & 3,780 & 22.12 & 730 \\
\hline 1997 & 36.97 & 44,800 & 34.66 & 30,500 & 46.58 & 10,800 \\
\hline 1998 & 39.64 & 62,200 & 43.10 & 46,900 & 40.69 & 11,600 \\
\hline 1999 & 18.01 & 9,050 & 21.01 & 9,180 & 18.83 & 1,130 \\
\hline 2000 & 26.09 & 30,800 & 27.52 & 21,200 & 36.85 & 10,100 \\
\hline 2001 & 29.49 & 40,500 & 30.94 & 31,700 & 39.23 & 13,800 \\
\hline 2002 & 43.97 & 73,600 & 44.34 & 51,900 & 53.60 & 18,400 \\
\hline 2003 & 26.04 & 32,600 & 24.86 & 21,600 & 27.41 & 4,160 \\
\hline Average & 30.40 & 37,900 & 29.72 & 26,000 & 32.09 & 5,940 \\
\hline Minimum & 10.63 & 1,920 & 11.38 & 1,760 & 11.14 & 100 \\
\hline Maximum & 51.71 & 117,000 & 52.71 & 73,800 & 58.61 & 26,700 \\
\hline
\end{tabular}

${ }^{1}$ Recalibrated values. 
Table 14. Comparison of Edwards aquifer recharge estimates from Hydrological Simulation Program—FORTRAN (HSPF) with historical (Puente method) U.S. Geological Survey recharge estimates for Hondo Creek and Verde Creek watersheds, south-central Texas, 1992-2003.

\begin{tabular}{|c|c|c|c|c|}
\hline \multirow[b]{2}{*}{ Year } & \multicolumn{2}{|c|}{ Hondo Creek watershed } & \multicolumn{2}{|c|}{ Verde Creek watershed } \\
\hline & $\begin{array}{l}\text { HSPF-simulated recharge } \\
\text { (acre-feet) }\end{array}$ & $\begin{array}{l}\text { Puente method recharge } \\
\text { (acre-feet) }\end{array}$ & $\begin{array}{l}\text { HSPF-simulated recharge } \\
\text { (acre-feet) }\end{array}$ & $\begin{array}{l}\text { Puente method recharge } \\
\text { (acre-feet) }\end{array}$ \\
\hline${ }^{\mathrm{T}} 1992$ & 117,000 & 209,000 & 73,800 & 133,000 \\
\hline 1993 & 17,100 & 17,900 & 16,000 & 18,200 \\
\hline 1994 & 26,000 & 15,500 & 20,400 & 16,300 \\
\hline 1995 & 23,300 & 18,100 & 17,900 & 22,200 \\
\hline 1996 & 3,800 & 1,530 & 3,780 & 5,570 \\
\hline${ }^{1} 1997$ & 44,800 & 61,600 & 30,500 & 55,800 \\
\hline${ }^{1} 1998$ & 62,200 & 64,500 & 46,900 & 62,600 \\
\hline 1999 & 9,050 & 20,400 & 9,180 & 19,900 \\
\hline 2000 & 30,800 & 14,600 & 21,200 & 21,000 \\
\hline 2001 & 40,500 & 39,800 & 31,700 & 39,300 \\
\hline${ }^{1} 2002$ & 73,600 & 135,000 & 51,900 & 156,000 \\
\hline 2003 & 32,600 & 22,800 & 21,600 & 22,100 \\
\hline Average & 40,100 & 51,700 & 28,700 & 47,700 \\
\hline
\end{tabular}

${ }^{1}$ Years of greater-than-average rainfall in both watersheds. 
Prepared by the USGS Texas Water Science Center:

8027 Exchange Drive

Austin, TX 78754-4733

Information regarding water resources in Texas is available at http: //tx.usgs.gov/ 